\title{
Chemical Variability and Biological Activities of Eucalyptus spp. Essential Oils
}

\author{
Luiz Claudio Almeida Barbosa ${ }^{1,2}$, Claudinei Andrade Filomeno ${ }^{2,3, *}$ and Robson Ricardo Teixeira ${ }^{2}$ \\ 1 Departament of Chemistry, ICEx, Universidade Federal de Minas Gerais, Av. Presidente Antônio Carlos, \\ 6627, Campus Pampulha, Belo Horizonte, MG 31270-901, Brazil; lcab@ufmg.br \\ 2 Departament of Chemistry, Universidade Federal de Viçosa, Av. P.H. Rolfs, S/N, Viçosa, MG 36570-900, \\ Brazil; robsonr.teixeira@ufv.br \\ 3 Instituto Federal do Espírito Santo, Av. Ministro Salgado Filho, 1000, Campus Vila Velha, Vila Velha, \\ ES 29106-010, Brazil \\ * Correspondence: claudinei@ifes.edu.br; Tel.: +55-27-988-075-055
}

Academic Editor: Olga Tzakou

Received: 3 October 2016; Accepted: 28 November 2016; Published: 7 December 2016

\begin{abstract}
Many plant species produce mixtures of odorous and volatile compounds known as essential oils (EOs). These mixtures play important roles in Nature and have been utilized by mankind for different purposes, such as pharmaceuticals, agrochemicals, aromatherapy, and food flavorants. There are more than 3000 EOs reported in the literature, with approximately 300 in commercial use, including the EOs from Eucalyptus species. Most EOs from Eucalyptus species are rich in monoterpenes and many have found applications in pharmaceuticals, agrochemicals, food flavorants, and perfumes. Such applications are related to their diverse biological and organoleptic properties. In this study, we review the latest information concerning the chemical composition and biological activities of EOs from different species of Eucalyptus. Among the 900 species and subspecies of the Eucalyptus genus, we examined 68 species. The studies associated with these species were conducted in 27 countries. We have focused on the antimicrobial, acaricidal, insecticidal and herbicidal activities, hoping that such information will contribute to the development of research in this field. It is also intended that the information described in this study can be useful in the rationalization of the use of Eucalyptus EOs as components for pharmaceutical and agrochemical applications as well as food preservatives and flavorants.
\end{abstract}

Keywords: essential oils; monoterpenes; insecticidal activity; antimicrobial activity; acaricidal activity; herbicidal activity; Eucalyptus; 1,8-cineole

\section{Introduction}

Nature is a precious reservoir of substances that can be explored for developing new pharmaceuticals. Several drugs for treating a variety of diseases have been discovered via screening of natural compounds obtained from animals, microorganisms, marine organisms, and plants. These drugs can be natural products per se or semi-synthetic analogs derived from an active natural product. Furthermore, they can be entirely synthetic compounds designed using natural products as models [1-6].

Natural products have also been directly utilized as pest control agents. Moreover, they have served as models for the development of new pesticides with potential commercial applications [7-13].

Although there are a large number of plant species, only approximately $10 \%$ produce mixtures of odorous and volatile compounds, collectively called essential or volatile oils [14]. Such essential oils (EOs) can be produced from all parts of plants (buds, gums, blossoms, flowers, leaves, stems, twigs, seeds, fruits, roots, wood or bark), depending upon the producing species. EOs are stored in 
several secretory structures such as epidermic cells, secretory hairs, secretory ducts, secretory cavities, glandular trichomes, or resin adducts [15-19]. EOs are generally hydrophobic liquids and soluble in alcohol, nonpolar or weakly polar solvents, waxes, and oils. They are slightly soluble in water and are usually colorless or pale yellow $[15,17,20]$. From a chemical standpoint, they are typically composed of hydrocarbons and oxygenated monoterpenes, sesquiterpenes and diterpenes, aromatic compounds (C6-C3 and C6-C1 compounds), and low molecular weight aliphatic compounds.

Some EOs play an important role in protecting plants against insect attack, fungi, bacteria and viruses and can also be important as a deterrent to herbivorous feeding [15,21-24]. EOs are also known to be involved in allelopathic interactions inhibiting seed germination and plant growth [25-28]. These properties have been investigated for the development of herbicides [29-31]. Within this context and considering the favorable biodegradability of essential oil components, they can be considered attractive alternative tools for controlling the growth of weeds [32]. EOs from a variety of plants are also endowed with antibacterial activities [33-36] as well as anti-inflammatory and antioxidant properties [37].

There are more than 3000 EOs described in the existing literature, with approximately 300 in commercial use, including those from various Eucalyptus species $[15,17,38,39]$. The Eucalyptus genus is represented by 900 species and subspecies. Based on morphological and molecular characteristics, Eucalyptus was reclassified in 1995 by Hill and Johnson [40]. According these authors, the Corymbia, previously classified as a subgenus of Eucalyptus, has been elevated to the rank of a separate genus with 113 known Corymbia species. Among then, Corymbia citriodora, C. maculata, C. ficifolia, C. ptychocarpa and $C$. torelliana are the best-known. Despite this reclassification, the names originally found in the references were used for the preparation of this review to facilitate the discussion.

The Eucalyptus corresponds to one of the principal genera of the Myrtaceae family, native to Australia and cultivated worldwide [17,41-44]. Eucalyptus trees have perennial leaves that are odorous because of the presence of EOs that are produced and stored in secretory cells. These EOs are aromatic, spicy, and colorless or pale yellow, although there are studies that have reported the color as being brownish or greenish [44].

EOs obtained from Eucalyptus are usually rich in monoterpenes and in some cases sesquiterpenes. Many such EOs are used for pharmaceutical purposes and in perfumery [45]. The eucalyptus EOs utilized as pharmaceuticals are rich in 1,8-cineole, whereas those used in perfumery are rich in citronellal, citral and geranyl acetate [46].

Considering the versatility of Eucalyptus EOs in terms of bioactivities as well as their industrial importance, the purpose of this study is to provide the readers with the latest information concerning the chemical composition and biological activities of EOs from different species of Eucalyptus. Two reviews about Eucalyptus EOs and biological activities have been recently published. One of them by Vuong et al. [47] that focused on anticancer properties of Eucalyptus EOs; the other by Zhang et al. [48] that described advances up to 2010 in terms of several biological activities. In this paper, from the 900 species and subspecies of the Eucalyptus genus, we have examined 68 species (three of them are hybrids). The studies associated with these species were conducted in 27 countries and the literature survey covers recent developments in the field. The review focused on the antimicrobial, acaricidal, insecticidal and herbicidal properties of Eucalyptus species. The information described can be useful in the rationalization of the use of Eucalyptus EOs as source of constituents for pharmaceutical and agrochemical applications as well as food preservatives.

\section{Chemical Variability of Eucalyptus EOs}

Although the EOs are found in the leaves of more than 300 species of Eucalyptus, fewer than 20 species have been commercially explored for EO production $[46,49]$. In terms of the chemical composition of these EOs, they are complex mixtures of substances, generally containing 20 to 80 compounds, differing in their concentrations. Terpenes and terpenoids are the major components found in EOs obtained from the leaves of Eucalyptus [38,50-55] as illustrated in Figure 1. 
<smiles>CC1=CC(=O)C(C(C)C)CC1</smiles>

Piperitone<smiles>Cc1ccc(C(C)C)cc1</smiles>
$p$-cymene<smiles>C/C=C(C)\C=C/C=C(C)C</smiles>

Alloocimene<smiles>CC(C)=CCCC(C)CC=O</smiles>

Citronellal<smiles>CC1=CCC(C(C)C)C=C1</smiles>

$\alpha$-phellandrene<smiles>CC1=CCC(C(C)C)=CC1</smiles>

$\gamma$-terpinene<smiles>CC(C)=CCCC(C)CCO</smiles>

Citronellol<smiles>CC1=CC2CC1CC21CC1</smiles>

$\alpha$-pinene<smiles>CC(=O)OCC=C(C)CCC=C(C)C</smiles>

Geranyl acetate<smiles>C=C[C@](C)(O)CCC=C(C)C</smiles>

Linalool<smiles>CC1=CCC(C(C)(C)O)CC1</smiles>

$\alpha$-terpineol<smiles>C=C1CCC2[C@H]3[C@@H]([C@@H]2[C@@H]1CO)C3(C)C</smiles>

Spathulenol<smiles>CC1(C)[C@H]2CC[C@@]1(C)CCO2</smiles>

1,8 -cineole<smiles>C=C(C)C1CC=C(C)CC1</smiles>

Limonene<smiles>CC1=CCC2(C(C)C)CC1C2</smiles>

$\alpha$-thujene

Figure 1. Some of the major constituents of the essential oils of Eucalyptus leaves.

The International Standard Organization (ISO) defines EOs as products obtained from parts of plants through hydrodistillation, steam distillation or dry distillation, as well as products obtained by a suitable mechanical process (for Citrus fruits). The definition of an essential oil excludes other aromatic/volatile products obtained by different extractive techniques such as extraction with solvents (concretes, absolutes), supercritical fluid extraction, and microwave-assisted extraction.

The composition of the EOs can vary according to the method and drying conditions applied to the vegetal material prior to extraction, and also according to the storage conditions [56-59]. The method of choice for a particular application depends on the material from which the EOs are to be extracted and also the type of application itself.

Concerning the extraction of EOs from Eucalyptus, hydrodistillation is typically the method of choice. The extraction yields range from $0.06 \%$ to $7 \%$ [60], and the chemical composition of the resulting EOs depends on the plant species and varieties. Within the same variety, the essential oil composition can vary according to geographical region, as reported in several studies $[15,17,39,61,62]$ (Table 1).

From Table 1, it can be noticed that the species E. camaldulensis, E. cinerea, E. citriodora, E. globulus, E. grandis, E. saligna and E. tereticornis are the ones which have received more attention in terms of their essential oil composition. A more detailed discussion regarding chemical aspects of EOs of these species is described below. 
Table 1. Some common chemical components of essential oils extracted from leaves of Eucalyptus spp. ${ }^{\text {a }}$.

\begin{tabular}{|c|c|c|c|c|}
\hline Eucalyptus spp. & Origin & Components of Eucalyptus EOs & EOs Yields (\%) & Reference \\
\hline \multirow{15}{*}{ E. camaldulensis } & Argentina & 1,8-cineole (19.1\%), $p$-cymene (17.9\%), $\beta$-phellandrene $(16.3 \%)$ & 0.38 & [63-65] \\
\hline & Brazil & 1,8-cineole $(52.8 \%)$, limonene $(14.2 \%), \gamma$-terpinene $(6.8 \%), \alpha$-pinene $(6.1 \%)$ & 0.63 & {$[66,67]$} \\
\hline & Brazil & 1,8 -cineole $(44.8 \%), \alpha$-phellandrene $(22.9 \%), p$-cymene $(9.8 \%)$ & 3.00 & [68] \\
\hline & Democratic Republic of the Congo & 1,8-cineole $(58.9 \%)$, myrtenol $(4.3 \%)$, myrtenal $(3.5 \%)$ & $0.30^{\mathrm{b}}$ & [53] \\
\hline & Egypt & 1,8-cineole $(60.3 \%), \alpha$-pinene $(13.6 \%), \gamma$-terpinene $(8.8 \%)$ & - & [69] \\
\hline & India & $\alpha$-phellandrene $(27.5 \%), \beta$-pinene $(23.5 \%), m$-cymene $(9.5 \%), 1,8$-cineole $(8.7 \%)$ & $1.97^{b}$ & [70] \\
\hline & Iran & 1,8 -cineole $(74.7 \%)$ & - & [71] \\
\hline & Kenya & 1,8 -cineole $(18.9 \%), \alpha$-cadinol (6.4\%), $\beta$-phellandrene $(2.6 \%)$ & - & [72] \\
\hline & Nigeria & 1,8-cineole $(70.4 \%), \beta$-pinene $(9.0 \%), \alpha$-pinene $(8.8 \%)$ & 0.26 & [73] \\
\hline & Northern Cyprus & 1,8-cineole (19.0\%), $\beta$-caryophyllene (11.6\%), carvacrol (9.1\%) & - & [74] \\
\hline & Pakistan & linalool (17.0\%), 1,8-cineole (16.1\%), $p$-cymene $(12.2 \%)$ & 1.90 & [75] \\
\hline & Spain & spathulenol $(41.5 \%), p$-cymene $(21.9 \%)$ & 0.71 & [76] \\
\hline & Taiwan & 1,8 -cineole $(29.6 \%)$, limonene $(15.2 \%)$, $\beta$-pinene $(9.9 \%), \alpha$-pinene $(9.7 \%)$ & 3.48 & [77] \\
\hline & Taiwan & $\alpha$-pinene $(22.5 \%), p$-cymene $(21.7 \%), \alpha$-phellandrene $(20.1 \%), 1,8$-cineole $(9.5 \%)$ & 0.57 & [78] \\
\hline & Tunisia & 1,8-cineole $(20.6 \%), \alpha$-pinene $(16.5 \%)$ & $0.76-1.42$ & {$[79,80]$} \\
\hline \multirow{8}{*}{ E. cinerea } & Argentina & 1,8-cineole $(88.5 \%), \alpha$-terpineol $(9.0 \%), \alpha$-pinene $(2.0 \%)$ & - & [81] \\
\hline & Argentina & 1,8-cineole $(79.8 \%), \alpha$-terpinyl acetate $(8.2 \%)$ & 2.48 & {$[63,64]$} \\
\hline & Argentina & 1,8-cineole $(62.1 \%), p$-cymene $(11.2 \%)$ & - & [82] \\
\hline & Argentina & 1,8 -cineole $(56.9 \%), \alpha$-pinene $(6.4 \%)$ & - & [83] \\
\hline & Brazil & 1,8 -cineole $(83.6 \%), \alpha$-terpinyl acetate $(5.4 \%), \alpha$-pinene $(5.0 \%)$ & $3.56-5.02$ & [84] \\
\hline & Brazil & 1,8 -cineole $(75.7 \%), \alpha$-terpineol $(9.7 \%), \alpha$-pinene $(6.2 \%)$ & 6.07 & [85] \\
\hline & Tunisia & 1,8 -cineole $(79.2 \%), \alpha$-terpinyl acetate $(5.4 \%), \alpha$-pinene $(4.1 \%)$ & 3.00 & [86] \\
\hline & Tunisia & 1,8-cineole $(70.4 \%), \alpha$-terpineol $(10.3 \%)$ & 3.90 & [87] \\
\hline \multirow{15}{*}{ E. citriodora } & Argentina & citronellal $(76.0 \%)$, iso-isopulegol $(9.0 \%)$, citronellyl acetate $(7.3 \%)$ & & [82] \\
\hline & Australia & citronellal $(68.9 \%)$, citronellol $(7.6 \%)$, isopulegol $(7.4 \%)$ & - & [88] \\
\hline & Benin & citronellal $(52.8 \%)$, citronellol $(20.0 \%)$, citronellyl acetate $(9.0 \%)$ & 4.60 & {$[89,90]$} \\
\hline & Brazil & citronellal $(94.9 \%)$, citronellyl acetate $(2.6 \%)$, trans caryophyllene $(2.5 \%)$ & - & [91] \\
\hline & Brazil & citronellal $(89.6 \%)$, citronellyl acetate $(3.3 \%), 1,8$-cineole $(2.9 \%)$ & - & [92] \\
\hline & Brazil & citronellal $(82.3 \%)$, citronellyl acetate $(7.8 \%)$, neothujan-3-ol $(6.8 \%)$ & 4.00 & [93] \\
\hline & Brazil & citronellal (76.0\%), neo-iso-3-thujanol (11.8\%) & 0.66 & {$[66,67]$} \\
\hline & Brazil & $\beta$-citronellal (71.8\%), (-)-isopulegol (7.3\%), isopulegol (4.3\%) & - & {$[94]$} \\
\hline & Brazil & citronellal $(71.8 \%)$, isopulegol $(4.3 \%)$ & - & [95] \\
\hline & Brazil & citronellal $(71.1 \%)$, citronellol $(8.8 \%)$ & - & [96] \\
\hline & Brazil & citronellal (67.5\%), citronellol (6.9\%), menthol (6.1\%) & - & [97] \\
\hline & Brazil & citronellal $(61.8 \%)$, isopulegol $(15.5 \%), \beta$-citronellol $(7.9 \%)$ & - & [98] \\
\hline & Brazil & citronellal $(64.9 \%)$, iso-isopulegol $(10.2 \%)$, citronellol $(8.3 \%)$ & 2.10 & [99] \\
\hline & China & citronellal $(65.9 \%)$, citronellol $(10.5 \%), 1,8$-cineole $(3.0 \%)$ & - & {$[100,101]$} \\
\hline & China & citronellal (55.3\%), citronellol (8.3\%) & - & [102] \\
\hline
\end{tabular}


Table 1. Cont

\begin{tabular}{|c|c|c|c|c|}
\hline Eucalyptus spp. & Origin & Components of Eucalyptus EOs & EOs Yields (\%) & Reference \\
\hline \multirow{11}{*}{ E. citriodora } & Colombia & citronellal (49.3\%), citronellol (13.0\%), isopulegol (12.9\%) & 0.70 & [103] \\
\hline & Colombia & citronellal $(40.0 \%)$, isopulegol $(14.6 \%)$, citronellol $(13.0 \%)$ & - & {$[104,105]$} \\
\hline & Democratic Republic of the Congo & citronellal (72.7\%), citronellol (6.3\%), eugenol (3.5\%) & $1.63^{\mathrm{b}}$ & [53] \\
\hline & India & citronellal $(52.2 \%)$, citronellol $(12.3 \%)$, isopulegol $(11.9 \%)$ & 0.60 & [26] \\
\hline & India & citronellal $(48.3 \%)$, citronellol $(21.9 \%)$, iso-isopulegol (12.7\%) & $2.36-4.80$ & [54] \\
\hline & Indonesia & citronellal (90.1\%), citronellol (4.3\%) & - & [106] \\
\hline & Kenya & 1,8-cineole $(11.2 \%)$, $\beta$-pinene (3.2\%), terpinen-4-ol (3.1\%) & - & [72] \\
\hline & Pakistan & citronellal $(22.3 \%)$, citronellol $(20.0 \%)$ & 1.82 & [75] \\
\hline & South Korea & citronellal $(73.0 \%)$, isopulegol $(6.7 \%)$ & - & [107] \\
\hline & Taiwan & citronellal $(49.5 \%)$, citronellol (11.9\%), iso-isopulegol (10.4\%) & 1.89 & [77] \\
\hline & Tunisia & 1,8-cineole $(54.1 \%), \alpha$-pinene $(23.6 \%)$ & 3.30 & {$[49,108]$} \\
\hline \multirow{27}{*}{ E. globulus } & Algeria & 1,8-cineole (55.3\%), spathulenol (7.4\%), $\alpha$-terpineol (5.5\%) & 2.53 & [109] \\
\hline & Argentina & 1,8-cineole $(77.9 \%), \alpha$-terpineol $(6.0 \%)$ & 2.25 & {$[63,64]$} \\
\hline & Argentina & 1,8-cineole $(76.7 \%), \alpha$-pinene $(11.1 \%)$ & 1.66 & {$[63,110]$} \\
\hline & Argentina & 1,8 -cineole $(52.3 \%-62.1 \%)$ & $1.31-1.49$ & [111] \\
\hline & Australia & 1,8 -cineole $(90.0 \%), \alpha$-pinene $(2.2 \%)$ & - & [112] \\
\hline & Australia & 1,8-cineole $(81.1 \%)$, limonene $(7.6 \%), \alpha$-pinene $(4.0 \%)$ & - & [113] \\
\hline & Brazil & 1,8 -cineole $(90.0 \%)$, tricyclene $(3.0 \%)$ & - & [114] \\
\hline & Brazil & 1,8 -cineole $(85.8 \%), \alpha$-pinene $(9.9 \%)$ & - & [91] \\
\hline & Brazil & 1,8-cineole $(83.9 \%)$, limonene $(8.2 \%), \alpha$-pinene $(4.2 \%)$ & - & {$[95,115]$} \\
\hline & Brazil & 1,8-cineole $(77.5 \%), \alpha$-pinene $(14.2 \%)$ & 3.10 & {$[116]$} \\
\hline & Democratic Republic of the Congo & 1,8 -cineole $(44.3 \%)$, camphene $(23.1 \%), \alpha$-pinene $(9.3 \%)$, globulol $(7.3 \%)$ & $1.87^{\mathrm{b}}$ & [53] \\
\hline & Egypt & 1,8 -cineole $(21.4 \%), o$-cimene $(21.4 \%), \alpha$-pinene $(6.7 \%)$, spathulenol $(6.3 \%)$ & - & [117] \\
\hline & Ethiopia & 1,8 -cineole $(63.0 \%), \alpha$-pinene $(16.1 \%)$ & - & [118] \\
\hline & India & 1,8 -cineole $(81.9 \%)$, limonene $(6.6 \%)$ & - & [119] \\
\hline & India & 1,8 -cineole $(68.8 \%), \alpha$-pinene $(2.8 \%)$ & - & [120] \\
\hline & India & 1,8 -cineole $(66.3 \%)$, cis-ocymene $(21.3 \%), \alpha$-terpinyl acetate $(3.4 \%)$ & - & [121] \\
\hline & India & 1,8-cineole $(44.4 \%)$, limonene $(17.8 \%), p$-cymene $(9.5 \%)$ & - & [43] \\
\hline & India & 1,8 -cineole $(33.6 \%), \alpha$-pinene $(14.2 \%)$, limonene $(10.1 \%)$ & - & [122] \\
\hline & Indonesia & 1,8-cineole $(86.5 \%), \alpha$-pinene $(4.7 \%)$ & - & [106] \\
\hline & Iran & 1,8 -cineole $(84.5 \%)$, limonene $(8.50 \%)$ & - & [123] \\
\hline & Iran & 1,8 -cineole $(47.2 \%)$, spathulenol $(18.1 \%), \alpha$-pinene $(9.6 \%)$ & - & [124] \\
\hline & Italy & 1,8 -cineole $(84.9 \%), \alpha$-pinene $(5.6 \%), p$-cymene $(5.3 \%)$ & - & [125] \\
\hline & Kenya & 1,8 -cineole $(17.2 \%), \alpha$-pinene $(7.1 \%)$, spathulenol $(6.5 \%)$ & - & [72] \\
\hline & Montenegro & 1,8 -cineole $(85.8 \%), \alpha$-pinene $(7.2 \%), \beta$-myrcene $(1.5 \%)$ & $1.80^{\mathrm{b}}$ & [126] \\
\hline & Morocco & 1,8 -cineole $(22.4 \%)$, limonene $(7.0 \%)$, solanone $(6.1 \%), \beta$-pinene $(5.2 \%)$ & 1.21 & [127] \\
\hline & Pakistan & 1,8-cineole $(56.5 \%)$, limonene $(28.0 \%)$ & 1.89 & [75] \\
\hline & Spain & 1,8 -cineole $(63.8 \%), \alpha$-pinene $(16.1 \%)$ & - & [128] \\
\hline
\end{tabular}


Table 1. Cont.

\begin{tabular}{|c|c|c|c|c|}
\hline Eucalyptus spp. & Origin & Components of Eucalyptus EOs & EOs Yields (\%) & Reference \\
\hline \multirow{5}{*}{ E. grandis } & Argentina & $\alpha$-pinene $(52.7 \%), 1,8$-cineole $(18.4 \%), p$-cymene $(8.7 \%)$ & 0.36 & {$[65,129,130]$} \\
\hline & Brazil & $p$-cymene $(59.6 \%), \gamma$-terpinene $(29.2 \%)$ & 0.26 & [68] \\
\hline & Brazil & $\alpha$-pinene $(40.6 \%), \gamma$-terpinene $(16.3 \%), p$-cymene $(13.1 \%)$ & 0.31 & {$[66,67]$} \\
\hline & Brazil & $\gamma$-terpinene $(16.8 \%)$, o-cymene $(16.7 \%)$, $\beta$-pinene $(11.5 \%)$ & 2.00 & [93] \\
\hline & Taiwan & 1,8-cineole $(19.8 \%), \alpha$-terpinyl acetate $(12.8 \%), \alpha$-pinene $(11.4 \%)$ & 3.01 & [77] \\
\hline \multirow{11}{*}{ E. saligna } & Argentina & 1,8-cineole $(93.2 \%)$ & - & [131] \\
\hline & Argentina & 1,8-cineole $(93.2 \%)$, limonene $(3.3 \%)$ & - & [82] \\
\hline & Argentina & 1,8 -cineole $(34.0 \%), p$-cymene $(21.3 \%), \gamma$-terpinene $(20.10 \%), \alpha$-pinene $(13.0 \%)$ & 0.36 & {$[63,64]$} \\
\hline & Brazil & 1,8-cineole $(45.2 \%), p$-cymene $(34.4 \%), \alpha$-pinene $(12.8 \%)$ & 0.50 & [116] \\
\hline & Brazil & $p$-cymene $(25.6 \%), \alpha$-terpineol $(9.3 \%), \alpha$-camphonellal $(8.0 \%), 1,8$-cineole $(6.2 \%)$ & 0.50 & [93] \\
\hline & Brazil & $\alpha$-pinene $(92.3 \%)$ & 1.42 & [68] \\
\hline & Brazil & $\alpha$-pinene $(45.1 \%), p$-cymene $(22.5 \%), \alpha$-pinene oxide $(11.3 \%)$ & 0.40 & [132] \\
\hline & Brazil & $\alpha$-pinene $(25.9 \%), p$-cymene $(24.4 \%), \gamma$-terpinene $(24.6 \%)$ & 0.19 & {$[66,67]$} \\
\hline & Democratic Republic of the Congo & 1,8-cineole $(61.3 \%)$, limonene $(10.1 \%), p$-cymene $(7.2 \%)$ & $0.78^{\mathrm{b}}$ & [53] \\
\hline & Kenya & $\alpha$-pinene $(24.4 \%), 1,8$-cineole $(24.3 \%), o$-cimene $(9.9 \%), \alpha$-terpineol $(8.8 \%)$ & 0.38 & [133] \\
\hline & Nigeria & $\alpha$-thujene $(63.8 \%), 1,8$-cineole $(12.3 \%)$ & 0.30 & [73] \\
\hline \multirow{6}{*}{ E. tereticornis } & Argentina & 1,8-cineole $(37.5 \%), p$-cymene $(22.0 \%), \gamma$-terpinene $(10.8 \%)$ & - & [82] \\
\hline & Argentina & $\beta$-phellandrene (22.6\%), 1,8-cineole (18.6\%), $p$-cymene (14.5\%), $\alpha$-phellandrene $(9.4 \%)$ & 0.60 & [63-65] \\
\hline & Benin & $p$-cymene $(31.1 \%), \beta$-phellandrene $(9.7 \%)$ & - & [134] \\
\hline & Benin & p-cymene $(16.7 \%)$, caryophyllene oxide $(14.2 \%)$, spathulenol $(13.5 \%)$, cryptone $(11.4 \%)$ & 1.00 & [89] \\
\hline & Brazil & $\beta$-pinene (22.4), 1,8-cineole (19.3\%), $\alpha$-pinene $(13.6 \%), \alpha$-phellandrene $(10.3 \%)$ & 2.30 & [68] \\
\hline & Democratic Republic of the Congo & $p$-cymene $(28.6 \%)$, cryptone $(17.8 \%), \alpha$-pinene $(8.3 \%)$ & $0.45^{\mathrm{b}}$ & [53] \\
\hline
\end{tabular}

The compounds are listed according to their decreasing q

leaves of Eucalyptus spp. is in Supplementary Materials. 


\subsection{Eucalyptus camaldulensis Dehnh}

The reported yields of EOs for E. camaldulensis range from $0.26 \%$ to $3.48 \%$ being the highest value found for plants cultivated in Taiwan [77]. In most E. camaldulensis EOs, 1,8-cineole is the major constituent, usually found in quantities above $50 \%$ in EOs extracted from plants cultivated in Egypt [69], the Democratic Republic of the Congo [53], Nigeria [73], Brazil [66,67] and Iran [71]. Different chemotypes of E. camaldulensis were identified for plants cultivated in Spain and Taiwan. Plants from Spain showed spathulenol and $p$-cymene as the major components [76], while for the species from Taiwan the principal constituents were $\alpha$-pinene, $p$-cymene and $\alpha$-phellandrene [78]. Plants cultivated in different countries produces EOs with variable composition as can be seen from Table 1 .

\subsection{Eucalyptus cinerea F. Muell. ex Benth}

The leaves of E. cinerea are aromatic, with great potential for EO production, and are used for ornamental purposes. There are few reports of its use in folk medicine [135]. Among all herein described Eucalyptus species, E. cinerea is the one that produces the highest amount of EOs, as illustrated by plants cultivated in Argentina that afford 2.48\% [63,64] and those from Paraná state in Brazil with $6.07 \%$ [85]. As observed from Table 1, the EOs produced by E. cinerea usually contain more than $80 \%$ of 1,8 -cineole [81,84] and such oils may serve as a source of this important compound for industrial applications.

\subsection{Eucalyptus citriodora Hook}

The EOs extracted from E. citriodora is the most important in terms of worldwide trading volume $[99,136]$. This species constitutes the richest and most economical known source of citronellal, a substance widely used in the manufacture of cosmetics and aromatization of cleaning products such as soaps and detergents. This compound also has antiseptic properties, which justifies its use as a cleaning agent and disinfectant of floors and toilets [137]. In terms of chemical composition, the EOs produced by E. citriodora are the most widely investigated among all eucalyptus species. In general, this species affords high yields of EOs, as observed in the studies from some plants cultivated in India [54] and in Benin [89] (4.8\% and 4.6\% yields, respectively). Lower EOs yielding species were found, however, among plants cultivated in India (0.6\%) [26], in São Paulo state, Brazil $(0.66 \%)[66,67]$ and Colombia (0.70\%) [103].

As observed from the data presented in Table 1, plants cultivated in several states in Brazil usually produce EOs with high $(>70 \%)$ citronellal content $[66,67,91-96]$. Other examples of plants that produce EOs with citronellal content above $70 \%$ are those from the Democratic Republic of the Congo [53]; South Korea [107] and Argentina [82]. Analysis of the data presented in Table 1 reveals that yields of EOs produced by these species and also their citronellal contents are influenced by the plant cultivation location.

As reported to date, only plants cultivated in Tunisia [49,108] and Kenya [72] do not present citronellal as the major component in their EOs. Therefore, these E. citriodora species represent different chemotypes producing EOs rich in 1,8-cineole and $\alpha$-pinene (the Tunisian species) and 1,8-cineole for species cultivated in Kenya.

\subsection{Eucalyptus globulus Labill}

The EOs produced by E. globulus, cultivated in several places, are the major commercial source of 1,8-cineole. The highest content of 1,8-cineole ( $>80 \%)$ in EOs of E. globulus was reported in studies carried out in Brazil in São Paulo state [114,115], in Minas Gerais state [91], and in Ceará state [95]. High 1,8-cineole content was also found in EOs from Australia (81.1\%-90.0\%) [112,113]; Indonesia (86.5\%) [106]; Montenegro (85.8\%) [126]; Italy (84.9\%) [125]; India (81.9\%) [119]; Iran [123].

A severe limitation on several studies with E. globulus EOs is the lack of information on the extraction yields. This fact precludes us from evaluating the potential commercial application of such 
plants as a source of 1,8-cineole. Therefore, the plants that produce EOs with high 1,8-cineole content should be further investigated in more details in case of a commercial interest.

\subsection{Eucalyptus grandis W. Hill ex Maiden}

As described for other eucalyptus species, different chemotypes were also reported for E. grandis. Thus, plants cultivated in Goiás state (Brazil) are representative of chemotypes with $\gamma$-terpinene, $o$-cymene and $\beta$-pinene as the major components of their EOs [93]. In another study conducted in Botucatu (São Paulo state, Brazil) the identified chemotype was characterized by large quantities of $\alpha$-pinene, $\gamma$-terpinene and $p$-cymene [66,67]. The main components in the EOs from plants found in the Taiwan chemotype [77] were 1,8-cineole, $\alpha$-terpinyl acetate and $\alpha$-pinene, while the same chemotypes cultivated in Argentina [130] showed the presence of $52.7 \%$ of $\alpha$-pinene, $18.4 \%$ of 1,8 -cineole and $8.7 \%$ of $p$-cymene. Concerning EO extraction yields, species cultivated in Botucatu and in Argentina are low yielding $(0.31 \%$ and $0.36 \%$, respectively) while good extraction yields were observed for plants from Goiás state (Brazil) and Taiwan (2.0\% and 3.01\%, respectively).

In Brazil E. grandis is widely cultivated and used for cellulose pulp and paper production. Since its leaves have a high EO content (2.0\%), further investigation to evaluate the use of such an industrial residue for EO production could constitute in a good business opportunity for the companies involved.

\subsection{Eucalyptus saligna Smith}

The species E. saligna is widely cultivated in Brazil for cellulose pulp production and is constituted of several chemotypes, some of them rich in 1,8-cineole. Another example of the 1,8-cineole chemotype is found in plants cultivated in the Democratic Republic of the Congo [53] which EO contained $61.3 \%$ of this component. Two studies conducted in Argentina $[63,64,82]$ found the same chemotypes producing EOs with 1,8-cineole contents equal to $93.2 \%$ and $34.0 \%$, respectively. Several studies carried out in Brazil, in different states, have revealed different EO compositions of E. saligna. A 1,8-cineole chemotype was found in plants cultivated in Rio Grande do Sul state [116]. Chemotypes presenting $\alpha$-pinene as major component were found in plants cultivated in Minas Gerais state [68], which presented $92.3 \%$ of this compound, and in São Paulo state $[66,67,132]$. Finally, species cultivated in Nigeria [73] constituted a chemotype rich in $\alpha$-thujene. In all the aforementioned studies of E. saligna EOs, the best extraction yields (1.42\%) were obtained in the state of Minas Gerais [68].

\subsection{Eucalyptus tereticornis Smith}

The yields of EOs from E. tereticornis cultivated in different places varied from $0.45 \%$ to $2.3 \%$. Two studies conducted in Benin found EOs presenting $p$-cymene as the main component $[89,134]$. The EOs of E. tereticornis cultivated in the Democratic Republic of the Congo also revealed $p$-cymene as the major component [53]. Lucia et al. [63,64] reported that E. tereticornis EOs are rich in $\beta$-phellandrene, 1,8-cineole and $p$-cymene. Toloza and co-workers [82] examined EOs containing 1,8-cineole, $p$-cymene, and $\gamma$-terpinene as the major components. A recent work by Filomeno and co-workers [68] reported that E. tereticornis, cultivated in Minas Gerais state in Brazil, produces high quantities (2.3\%) of EOs rich in $\beta$-pinene, 1,8 -cineole and $\alpha$-pinene. This plant has a potential to be commercially explored as a source of EOs.

Based on the data described above, a large chemical variability is observed among Eucalyptus EO species. Such variation can be attributed to several factors including climate, soil type, plant age, nature (wet or dried) of the material used in the extraction, vegetative cycle stage, and time of the day when harvesting is done $[35,95,99,138-141]$.

Since the chemical composition of the Eucalyptus EOs is directly associated with their biological activities, the following discussion will be focused on such activities and on the multiple applications of such EOs. 


\section{Biological Activities of Eucalyptus EOs}

Several studies on antioxidant and antimicrobial activities of EOs from eucalyptus have been published in recent years $[14,15,17,21,49,142-148]$. Significant insecticide, antibacterial and fungicide effects have also been observed for EOs produced by Eucalyptus species $[53,63,66,75,106]$. Antimicrobial, acaricidal, insecticidal and herbicidal activities associated with EOs from the leaves of Eucalyptus are reported in several articles each year, demonstrating the importance of this research field. Such bioactivities are highly dependent on the EOs chemical composition, as discussed and illustrated in the following discussion.

\subsection{Antimicrobial Activity}

Eucalyptus EOs were evaluated against several Gram-positive and Gram-negative bacterial strains (Table 2) as well as against various fungal species (Table 3). The EOs showed different degrees of efficiency against the evaluated species. Among the bacterial strains, the pathogenic Gram-positive Staphylococcus aureus was most sensitive to EOs obtained from several Eucalyptus species. From the data available, Pseudomonas aeruginosa corresponded to the most resistant bacterial species. The yeast species Candida albicans also exhibited high sensitivity to the EOs.

\subsubsection{Antibacterial Activity}

The EOs from E. staigeriana presented high antimicrobial activity against all evaluated microorganisms (Table 2). By using the agar diffusion method, E. staigeriana EOs presented the highest activity against $S$. aureus with inhibition zone diameter (izd) superior to $90 \mathrm{~mm}$ (the growth of the microorganism was inhibited over the entire Petri dish). This value was four times superior to the inhibition zone diameter caused by chloramphenicol, the commercial antibiotic used as positive control in the biological assays [17]. In the same investigation, it was demonstrated that E. dives EOs were also very effective against $S$. aureus (izd $52.3 \mathrm{~mm}$ in diameter, a value approximately two times higher than the izd observed for chloramphenicol).

Derwich et al. [127] have demonstrated the efficiency of E. globulus EOs against Gram-negative E. coli and Gram-positive S. aureus and S. intermedius. These authors found that E. globulus EOs presented excellent activity on $E$. coli in the agar disc diffusion assay (izd $=48.15 \mathrm{~mm}$ ) compared to S. aureus (izd $=13.5 \mathrm{~mm}$ ) and S. intermedius (izd $=10.26)$. The minimum inhibitory concentration (MIC) for $E$. coli corresponded to $0.15 \mathrm{mg} / \mathrm{mL}$ while for $S$. aureus and $S$. intermedius the values corresponded to $0.75 \mathrm{mg} / \mathrm{mL}$ and $1.08 \mathrm{mg} / \mathrm{mL}$, respectively.

The effects of E. globulus EOs on 14 food spoilage microorganisms have been investigated using liquid and vapour fase agar dilution/well diffusion method and disc volatilization method [43]. The MIC found from such methods varied in the range of $2.25-9.0 \mathrm{mg} / \mathrm{mL}$ for bacterial and fungal strains. It was observed that MIC obtained for Gram-positive B. subtilis and S. aureus were lower than MIC values found for Gram-negative E. coli, P. aeruginosa, and P. fluorescens [43]. In general, significantly higher antimicrobial activities were observed in the vapour phase. As previously mentioned, 1,8-cineole is the main component of E. globulus EOs. It has been demonstrated that this compound has antimicrobial activity against several microorganisms including S. aureus [149], E. coli and B. subtilis $[150,151]$. 
Table 2. Eucalyptus spp. essential oils with antibacterial activities.

\begin{tabular}{|c|c|c|}
\hline Eucalyptus spp. & Target Species & Reference \\
\hline E. alba & $\begin{array}{l}\text { Bacillus subtilis, Citrobacter diversus, Escherichia coli, Klebsiella oxytoca, Klebsiella pneumoniae, Proteus vulgaris, } \\
\text { Pseudomonas aeruginosa, Salmonella typhimurium, Staphylococcus aureus }\end{array}$ & {$[53,73]$} \\
\hline E. astringens & Bacillus cereus, Escherichia coli, Listeria ivanovii & [86] \\
\hline E. bicostata & Bacillus cereus, Listeria ivanovii, Staphylococcus aureus, Streptococcus pneumoniae & {$[86,152]$} \\
\hline E. botryoides & Escherichia coli, Staphylococcus aureus & [49] \\
\hline E. camaldulensis & $\begin{array}{c}\text { Bacillus cereus, Bacillus subtilis, Citrobacter diversus, Escherichia coli, Klebsiella oxytoca, Klebsiella pneumoniae, Listeria monocytogenes, } \\
\text { Proteus vulgaris, Pseudomonas aeruginosa, Shigella flexneri, Staphylococcus aureus }\end{array}$ & {$[53,70,73-75]$} \\
\hline E. cinerea & $\begin{array}{c}\text { Bacillus cereus, Escherichia coli, Listeria ivanovii, Pseudomonas aeruginosa, Staphylococcus aureus, Staphylococcus epidermidis, } \\
\text { Streptococcus pyogenes }\end{array}$ & {$[84-87]$} \\
\hline E. citriodora & $\begin{array}{c}\text { Bacillus subtilis, Citrobacter diversus, Enterococcus faecalis, Escherichia coli, Klebsiella oxytoca, Klebsiella pneumoniae, Proteus vulgaris, } \\
\text { Pseudomonas aeruginosa, Salmonella choleraesuis, Salmonella typhimurium, Shigella flexneri, Staphylococcus aureus }\end{array}$ & {$[49,53,75,93,106]$} \\
\hline E. cloeziana & Escherichia coli, Staphylococcus aureus & [93] \\
\hline E. crebra & Bacillus subtilis, Escherichia coli, Staphylococcus aureus & [75] \\
\hline E. deglupta & $\begin{array}{l}\text { Bacillus cereus, Bacillus subtilis, Escherichia coli, Klebsiella oxytoca, Klebsiella pneumoniae, Pseudomonas aeruginosa, } \\
\text { Salmonella typhimurium, Shigella flexneri, Staphylococcus aureus }\end{array}$ & {$[53,73]$} \\
\hline E. diversifolia & Enterococcus faecalis, Escherichia coli, Staphylococcus aureus & [153] \\
\hline E. dives & Escherichia coli, Listeria monocytogenes, Pseudomonas fragi, Salmonella typhimurium, Staphylococcus aureus & {$[17,154]$} \\
\hline E. globulus & $\begin{array}{l}\text { Acinetobacter baumannii, Bacillus cereus, Bacillus subtilis, Citrobacter diversus, Enterococcus faecalis, Escherichia coli, } \\
\text { Fusobacterium nucleatum, Klebsiella oxytoca, Klebsiella pneumoniae, Porphyromonas gingivalis, Pseudomonas aeruginosa, } \\
\text { Pseudomonas fluorescens, Salmonella paratyphi, Salmonella typhi, Salmonella typhimurium, Shigella, Staphylococcus aureus, } \\
\text { Staphylococcus intermedius, Staphylococcus sciuri, Staphylococcus warneri, Streptococcus pyogenes }\end{array}$ & {$[43,53,75,106,109,118,123-128]$} \\
\hline E. gracilis & Klebsiella pneumoniae, Listeria monocytogenes & [155] \\
\hline E. grandis & Escherichia coli, Salmonella choleraesuis, Staphylococcus aureus & [93] \\
\hline E. lehmannii & Bacillus cereus, Escherichia coli, Pseudomonas aeruginosa, Staphylococcus aureus & {$[86,152]$} \\
\hline E. leucoxylon & Bacillus cereus, Escherichia coli & [86] \\
\hline E. maidenii & Bacillus cereus, Enterococcus faecalis, Escherichia coli, Listeria ivanovii, Staphylococcus aureus & {$[86,152]$} \\
\hline E. melanophloia & Bacillus subtilis, Escherichia coli, Staphylococcus aureus & [75] \\
\hline E. microcorys & Staphylococcus aureus & [93] \\
\hline
\end{tabular}


Table 2. Cont.

\begin{tabular}{|c|c|c|}
\hline Eucalyptus spp. & Target Species & Reference \\
\hline E. microtheca & Bacillus subtilis, Escherichia coli, Staphylococcus aureus & [75] \\
\hline E. odorata & $\begin{array}{c}\text { Enterococcus faecalis, Escherichia coli, Haemophilus influenzae, Streptococcus agalactiae, Staphylococcus aureus, } \\
\text { Streptococcus pneumoniae, Streptococcus pyogenes }\end{array}$ & [152] \\
\hline E. oleosa & Klebsiella pneumoniae, Listeria monocytogenes & [155] \\
\hline E. radiata & Acinetobacter baumannii, Escherichia coli, Klebsiella pneumoniae, Pseudomonas aeruginosa, Salmonella typhimurium & [128] \\
\hline E. robusta & $\begin{array}{c}\text { Bacillus subtilis, Escherichia coli, Klebsiella oxytoca, Klebsiella pneumoniae, Pseudomonas aeruginosa, Salmonella typhimurium, } \\
\text { Shigella flexneri, Staphylococcus aureus }\end{array}$ & {$[53,132]$} \\
\hline E. saligna & $\begin{array}{c}\text { Bacillus cereus, Bacillus subtilis, Citrobacter diversus, Escherichia coli, Klebsiella oxytoca, Klebsiella pneumoniae, } \\
\text { Pseudomonas aeruginosa, Salmonella choleraesuis, Staphylococcus aureus }\end{array}$ & {$[53,73,93,132]$} \\
\hline E. olida & Staphylococcus aureus & [17] \\
\hline E. ovata & Escherichia coli & [49] \\
\hline E. pellita & Bacillus subtilis, Escherichia coli, Pseudomonas aeruginosa, Staphylococcus aureus & [156] \\
\hline E. platypus & Enterococcus faecalis & [152] \\
\hline E. propinqua & $\begin{array}{c}\text { Bacillus subtilis, Citrobacter diversus, Klebsiella oxytoca, Klebsiella pneumoniae, Salmonella typhimurium, Shigella flexneri, } \\
\text { Staphylococcus aureus }\end{array}$ & [53] \\
\hline E. radiata & Enterococcus faecalis, Escherichia coli, Klebsiella pneumoniae, Pseudomonas aeruginosa, Staphylococcus aureus & [106] \\
\hline E. salmonophloia & Klebsiella pneumoniae, Listeria monocytogenes & [155] \\
\hline E. salubris & Klebsiella pneumoniae, Listeria monocytogenes & [155] \\
\hline E. sargentii & $\begin{array}{c}\text { Bacillus subtilis, Escherichia coli, Klebsiella pneumoniae, Proteus vulgaris, Pseudomonas aeruginosa, Shigella dysenteriae, } \\
\text { Staphylococcus aureus, Staphylococcus epidermidis }\end{array}$ & [157] \\
\hline E. sideroxylon & Bacillus cereus, Listeria ivanovii & [86] \\
\hline E. staigeriana & Enterococcus faecalis, Staphylococcus aureus & [17] \\
\hline E. tereticornis & $\begin{array}{c}\text { Bacillus subtilis, Citrobacter diversus, Corynebacteriaceae spp., Escherichia coli, Klebsiella oxytoca, Klebsiella pneumoniae, } \\
\text { Proteus vulgaris, Pseudomonas aeruginosa, Shigella flexneri }\end{array}$ & {$[53,134]$} \\
\hline E. urophylla & Bacillus subtilis, Escherichia coli, Klebsiella oxytoca, Klebsiella pneumoniae & [53] \\
\hline
\end{tabular}


Table 3. Eucalyptus spp. essential oils with antifungal activities.

\begin{tabular}{|c|c|c|}
\hline Eucalyptus spp. & Target Species & Reference \\
\hline E. astringens & Candida albicans, Microsporum canis & [152] \\
\hline E. bicostata & Candida albicans & [152] \\
\hline E. camaldulensis & $\begin{array}{r}\text { Alternaria alternata, Aspergillus clavatus, Aspergillus niger, Candida albicans, Chaetomium globosum, Cladosporium cladosporioides, Lenzites sulphureus, Myrothecium verrucaria, } \\
\text { Penicillium citrinum, Phanerochaete chrysosporium, Phaeolus schweintizii, Rhizopus solani, Trametes versicolor, Trichoderma viride }\end{array}$ & {$[69,73,75,77]$} \\
\hline E. cinerea & Candida albicans & {$[84,85]$} \\
\hline E. citriodora & $\begin{array}{l}\text { Aspergillus clavatus, Aspergillus niger, Aspergillus spp., Botrytis cinerea, Chaetomium globosum, Cladosporium cladosporioides, Colletotrichum gloeosporioides, Colletotrichum musae, } \\
\text { Cryphonectria parasitica, Fusarium oxysporum, Lenzites sulphureus, Myrothecium verrucaria, Penicillium citrinum, Phaeolus schweintizii, Phanerochaete chrysosporium, } \\
\text { Phytophthora cactorum, Pyricularia grisea, Pythium ultimum, Rhizoctonia solani, Rhizopus solani, Trametes versicolor, Trichoderma viride }\end{array}$ & {$[75,77,88,98,107]$} \\
\hline E. crebra & Aspergillus niger, Rhizopus solani & [75] \\
\hline E. deglupta & Candida albicans & [73] \\
\hline E. dives & Candida albicans, Saccharomyces cerevisiae & [17] \\
\hline E. erythrocorys & Bipolaris sorokiniana, Botrytis cinerea & [158] \\
\hline E. globulus & $\begin{array}{c}\text { Aspergillus flavus, Aspergillus niger, Aspergillus parasiticus, Aspergillus spp., Candida albicans, Fusarium oxysporum, Mucor spp., Penicillium digitatum, Rhizopus nigricans, } \\
\text { Rhizopus solani, Saccharomyces cerevisiae, Trichophyton spp. }\end{array}$ & {$[43,75,114,118,126]$} \\
\hline E. gracilis & Aspergillus ochraceus, Candida albicans, Mucor ramamnianus, Saccharomyces cerevisiae & [155] \\
\hline E. grandis & $\begin{array}{c}\text { Aspergillus clavatus, Aspergillus niger, Chaetomium globosum, Cladosporium cladosporioides, Lenzites sulphureus, Myrothecium verrucaria, Penicillium citrinum, Phaeolus schweintizii, } \\
\text { Phanerochaete chrysosporium, Trametes versicolor, Trichoderma viride }\end{array}$ & [77] \\
\hline E. maidenii & Candida albicans, Trichophyton soudanense & [152] \\
\hline E. melanophloia & Aspergillus niger, Rhizopus solani & [75] \\
\hline E. microtheca & Aspergillus niger, Rhizopus solani & [75] \\
\hline E. odorata & Candida albicans, Microsporum canis, Scopulariopsis brevicaulis, Trichophyton rubrum, Trichophyton soudanense & [152] \\
\hline E. oleosa & Aspergillus ochraceus, Candida albicans, Mucor ramamnianus, Saccharomyces cerevisiae & [155] \\
\hline E. robusta & Candida albicans & [132] \\
\hline E. saligna & Candida albicans & {$[73,132]$} \\
\hline E. olida & Candida albicans & [17] \\
\hline E. platyphylla & Deightoniella torulosa & [159] \\
\hline E. salmonophloia & Aspergillus ochraceus, Candida albicans, Mucor ramamnianus, Saccharomyces cerevisiae & [155] \\
\hline E. salubris & Aspergillus ochraceus, Candida albicans, Mucor ramamnianus, Saccharomyces cerevisiae & [155] \\
\hline E. sargentii & Aspergillus niger, Candida albicans & [157] \\
\hline E. sideroxylon & Microsporum canis & [152] \\
\hline E. smithii & Microsporum canis, Microsporum gypseum, Trichophyton mentagnophytes, Trichophyton rubrum & [160] \\
\hline E. staigeriana & Candida albicans & [17] \\
\hline E. tereticornis & Hansenula spp., Saccharomyces spp., Sporobolomyces, Torulopsis candida & [134] \\
\hline E. urophylla & $\begin{array}{c}\text { Aspergillus clavatus, Aspergillus niger, Chaetomium globosum, Cladosporium cladosporioides, Lenzites sulphureus, Myrothecium verrucaria, Penicillium citrinum, } \\
\text { Phanerochaete chrysosporium, Phaeolus schweintizii, Trametes versicolor, Trichoderma viride }\end{array}$ & [77] \\
\hline
\end{tabular}


Vratnica and co-workers [126] investigated the antimicrobial effects of E. globulus EOs against 17 microorganisms, including food poisoning and spoilage bacteria and human pathogens. In general, the EOs were highly active against the evaluated microorganisms. The agar disc diffusion method was utilized and filter paper discs were impregnated with E. globulus EOs (5, 10, 15, 20 and $30 \mu \mathrm{L})$. In these assays, the highest inhibition zone diameter (izd) values were observed for S. pyogenes (25-51 mm), S. aureus (22-48 $\mathrm{mm})$, and E. coli $(23-47 \mathrm{~mm})$. The broth microdilution method was used to determine MIC which ranged from $0.09 \mathrm{mg} / \mathrm{mL}$ to $3.13 \mathrm{mg} / \mathrm{mL}$. The highest MIC values were found for P. aeruginosa and Salmonella infantis $(3.13 \mathrm{mg} / \mathrm{mL})$ and the lowest for S. aureus, E. coli and S. pyogenes $(0.09 \mathrm{mg} / \mathrm{mL})$. In this work, no information about the compounds possibly responsible for the biological activity was provided.

The EOs from E. camaldulensis were tested against a panel of 12 bacteria strains, and the most sensitive microorganism was B. subtilis. For this microorganism, the EOs caused izds in the range of $19.3 \mathrm{~mm}$ to $29.3 \mathrm{~mm}$ at different volumes $(20,30,40,50$ and $100 \mu \mathrm{L})$ in the agar diffusion method. When tested against L. monocytogenes and S. aureus, the EOs caused significant growth inhibition of the microorganisms, as attested by the corresponding izds ranging from 14.6 to $25.0 \mathrm{~mm}$ [70].

The biological assays conducted with EOs of $E$. odorata displayed the best results against $S$. aureus $(\mathrm{izd}=27.4 \mathrm{~mm})$ as determined in the agar diffusion method, followed by $S$. agalactiae $(\mathrm{izd}=19.4 \mathrm{~mm})$, H. influenzae $(\mathrm{izd}=19.2 \mathrm{~mm})$, S. pyogenes $(\mathrm{izd}=19.0 \mathrm{~mm})$ and S. pneumoniae $(\mathrm{izd}=17.4 \mathrm{~mm})$. Moreover, E. maidenii exhibited good activity against $S$. aureus (izd $=22.8 \mathrm{~mm})[87,152]$.

Antimicrobial activities of Eucalyptus spp. EOs against resistant bacterial strains have also been described. For instance, P. aeruginosa is known for its high intrinsic resistance against antibiotics. This fact has been attributed to the very restrictive outer membrane barrier of the bacteria, being highly resistant even to synthetic drugs $[17,49]$. The EOs of E. camaldulensis and E. tereticornis exhibited relevant activity against $P$. aeruginosa (izd $\sim 16.0 \mathrm{~mm}$ ) [53]. The EOs from E. cinerea were less active (izd $=7.0 \mathrm{~mm}$ ) when tested against $P$. aeruginosa [84].

In general, Gram-positive bacterial strains are more sensitive to Eucalyptus EOs than the Gram-negative ones $[17,43,84]$. This can be rationalized considering that Gram-negative bacteria possess a lipopolysaccharide membrane which is restrictive to the diffusion of hydrophobic compounds. In addition, the direct contact between the hydrophobic components of the EOs and the phospholipid bilayer of the cell membrane can occur in Gram-positive bacteria. As a consequence, the components exert their effects such as increase in the permeability to ions, leakage of vital intracellular components or compromise bacterial enzymes [43,84].

\subsubsection{Antifungal Activity}

Eucalyptus EOs also cause growth inhibition of some fungal species (Table 3), as in the case of $C$. albicans. Vratnica and co-workers [126] reported that E. globulus EOs were two times more effective (izd $=14-46 \mathrm{~mm})$ than nystatin, a drug used to treat fungal infections on the skin, mouth, vagina, and intestinal tract. The authors attributed this effect to the high content of 1,8-cineole in E. globulus EOs $(85.8 \%)$. This information should be taken with caution since in another study the correlation between 1,8-cineole content and antifungal activity was not confirmed [77]. Gilles and co-workers [17] reported the effect of E. staigeriana $(\mathrm{izd}=26.7 \mathrm{~mm})$, E. dives $(\mathrm{izd}=15.4 \mathrm{~mm})$ and E. olida $(\mathrm{izd}=12.6 \mathrm{~mm})$ EOs on C. albicans. In this study, the superior antifungal activity of E. staigeriana EOs was attributed to the presence of 1,8-cineole (34.8\%). Low activity against $C$. albicans was observed for EOs extracted from E. robusta and E. saligna, both without 1,8-cineole [132]. It should be noted that in the above cited studies no bioassays were conducted with pure 1,8-cineole, which could evaluate if 1,8-cineole has synergistic or antagonistic effect with other components of the EOs.

Tyagi and Malik [43] investigated the effect of EOs from E. globulus on several fungal species and reported MIC values ranging from 2.25 to $9 \mathrm{mg} / \mathrm{mL}$. The superior limit value was observed for P. digitatum and A. niger. For A. flavus, R. nigricans and F. oxysporum a MIC of $4.5 \mathrm{mg} / \mathrm{mL}$ was found, while for Mucor spp. and C. albicans MIC of $2.25 \mathrm{mg} / \mathrm{mL}$ was reported. 
In a recent study, it has been found that EOs from E. erythrocorys significantly reduced the growth of fungal species B. sorokiniana $(79.6 \%)$ and B. cinerea (78.5\%) [158].

The evaluation of antifungal activity of E. citriodora EOs, in concentration of $10 \mathrm{mg} /$ disc, revealed that these EOs completely inhibit the growth of $C$. cladosporioide, $M$. verrucaria and $T$. viride. On the contrary, the growth of A. clavatus, A. niger and P. citrinum were partially inhibited $(90.7 \%, 54.6 \%$ and $86.0 \%$, respectively). Such antifungal activities were ascribed to the main components of E. citriodora EOs, namely citronellal (49.5\%) and citronellol (11.9\%) [77].

Lipid peroxidation and microbial contamination are two problems related to deterioration of food, an important issue for the food industry [39]. The addition of antioxidants is a well known strategy used to retard or even stop oxidation processes in food. Due to the carcinogenicity associated with some synthetic antioxidants, their use is restricted. In this context, an increased interest in the use of natural additives to control food oxidation has been observed. The use of EOs has been considered by the food industries as an alternative to overcome food deterioration [161,162]. Natural products presenting antioxidant activity has also been taken into consideration since some compounds with antioxidant activity can also be utilized as antimicrobials $[37,163]$.

Infections caused by fungi and bacteria represent an important issue due to development of species resistant to well known fungicides and antibiotics [164]. Considering the relevant information available in the literature concerning the antimicrobial activity of Eucalyptus EOs, the employment of such can also be considered a viable alternative to overcome the resistance problem.

Synthetic fungicides are typically employed to prevent the contamination of food commodities from fungal deterioration as weel as from mycotoxin contaminations. However, the use of such substances is not free from side effects, as residual toxicity that contributes to the development of fungal resistance. This is particularly true when the fungi are exposed to fungicide sub-lethal concentrations. The use of EOs has been considered as an alternative to overcome the reported problems associated with synthetic fungicides and protection of food commodities [159,165]. Althought a promising strategy, further investigation in this area is still required to achieve a commercial product.

\subsection{Acaricidal Activity}

An acaricide can be defined as any substance or mixture of substances intended to prevent, destroy, repel, or mitigate ticks and mites. A number of studies have demonstrated the acaricidal effects of EOs obtained from different species of Eucalyptus (Table 4).

Table 4. Eucalyptus spp. essential oils with acaricidal activities.

\begin{tabular}{ccc}
\hline Eucalyptus spp. & Target Species & Reference \\
\hline E. approximans & Tetranychus urticae & {$[166]$} \\
E. bicostata & Tetranychus urticae & {$[166]$} \\
E. camaldulensis & Varroa destructor & {$[71]$} \\
E. citriodora & Boophilus microplus, Dermanyssus gallinae, Neoseiulus californicus, Tetranychus urticae & {$[91,100-102]$} \\
E. globulus & Boophilus microplus & {$[91]$} \\
E. maidenii & Tetranychus urticae & {$[166]$} \\
E. sideroxylon & Tetranychus urticae & {$[166]$} \\
E. staigeriana & Boophilus microplus, Dermanyssus gallinae & {$[91,102]$} \\
E. tereticornis & Amblyoma variegatum & {$[134]$} \\
\hline
\end{tabular}

The effects of EOs from E. citriodora, E. globulus and E. staigeriana on the tick species B. microplus were evaluated at several doses $(1 \%, 5 \%, 10 \%, 20 \%$ and $30 \%$ in methanol). The EOs from E. citriodora and E. staigeriana were the most active, causing $100 \%$ mortality of the larvae at $10 \%$ concentration. To achieve the same $100 \%$ mortality, it was required $20 \%$ of the EOs of E. globulus [91].

The EOs from E. citriodora are also toxic to the mite species T. urticae and N. californicus. A mortality bioassay was used to determine the $\mathrm{LD}_{50}$ of $\mathrm{EOs}$ (LD stands for lethal dose; $\mathrm{LD}_{50}$ denotes the dose likely to cause death in $50 \%$ of mites). The determined $\mathrm{LD}_{50}$ values were $19.3 \mu \mathrm{g} / \mathrm{cm}^{3}$ for T. urticae and $21.4 \mu \mathrm{g} / \mathrm{cm}^{3}$ for N. californicus [100]. 
Acaricidal effects were observed for EOs of E. approximans, E. bicostata, E. maidenii and E. sideroxylon on T. urticae females. At the concentrations of $0.5 \%$ and $1.0 \%$, the reported observed mortalities were as follows: E. approximans (67\% at $0.5 \% ; 83.1 \%$ at $1.0 \%)$, E. bicostata $(67.8 \%$ at $0.5 \%$ and $82.5 \%$ at $1.0 \%$ ), E. maidenii $(82.2 \%$ at $0.5 \%$ and $100.0 \%$ at $1.0 \%)$, E. sideroxylon (78.8\% at $0.5 \%$ and $79.4 \%$ at $1.0 \%$ ) [166].

The contact toxicity assay was used to evaluate the effects of E. citriodora EOs on the mite species D. gallinae. Using a dose of $0.21 \mathrm{mg} / \mathrm{cm}^{2}$ and after $24 \mathrm{~h}$ of exposure, $85 \%$ mortality was observed [102]. The effect of E. citriodora EOs was tested on larvae of the mite species Amblyomma cajennense and Anocentor nitens. In the biological evaluation, the concentrations ranged from $6.25 \%$ to $50 \%$. For A. cajennense, the acaricidal effect varied from $10.8 \%$ to $53.1 \%$ mortality; for A. nitens, a more sentitive species, the mortality ranged from $20.1 \%$ to $100 \%$ [167].

The acaricidal activity of EOs from E. camaldulensis on $V$. destructor mite was also investigated and a $\mathrm{LD}_{50}$ of $1.74 \mu \mathrm{L} / \mathrm{L}$ of air was found [71].

From the surveyed literature, it was clear that the acaricidal effects of EOs from eucalyptus in some cases are high and could lead to the development of an environmental friendly commercial products to control such parasites. However, the works reported are limited to nine species of eucalyptus, concentrated in five countries. Therefore, considering the large disponibility and diversity in chemical composition of EOs from eucalyptus, we believe that EOs endowed with more potent and specific acaricidal activities are still to be discovered and converted into commercial products.

\subsection{Insecticidal Activity}

There are more than 1,000,000 reported species of insects, with approximately 10,000 of them showing crop-eating behavior; of these, approximately 700 species cause the majority of global pest-related damage to crops. Moreover, several diseases that affect man are transmitted by insects [168]. Therefore, controlling insects is highly desirable and necessary to improve human quality of life and health. Compounds obtained from natural sources have been investigated for their insecticidal activities [169-171]. Many such compounds have been used as models for the development of active ingredients to control insects [172-185]. In this regard, EOs have attracted the attention of researchers as an alternative to synthetic chemical-based insect control [186-193]. As shown in Table 5, EOs from many Eucalyptus species show positive results in controlling a variety of insect species.

The insecticidal activity of EOs from E. globulus was evaluated against the larvae and pupae stages of house fly M. domestica (Diptera: Muscidae). The effects of the EOs were assessed via fumigation and contact bioassays. Considering the larvae stage, in the contact assay the observed lethal concentration ( $\mathrm{LC}_{50}$ ) ranged from 2.73 to $0.60 \mu \mathrm{L} / \mathrm{cm}^{2}$ for different days of observation, while the $50 \%$ lethality time $\left(\mathrm{LT}_{50}\right)$ varied from 1.7 to 6 days. The observed $\mathrm{LC}_{50}$ values in the fumigation test were 66.1 and $50.1 \mu \mathrm{L} / \mathrm{L}$ after 24 and $48 \mathrm{~h}$, respectively. Pupicidal activity was reported in terms of inhibition percentage rate (IPR) which was $36.0 \%$ to $93.0 \%$ for contact assay and $67.9 \%$ to $100 \%$ for fumigation test [122]. In another investigation, the EOs of $E$. cinerea were evaluated against adult stage of M. domestica via fumigation assays. An $\mathrm{LC}_{50}$ of $5.5 \mathrm{mg} / \mathrm{dm}^{3}$ was found and the mortality of the insects was observed in a period of time of less than $15 \mathrm{~min}$ [81]. The major component in the oil used in this work was 1,8-cineole (56.9\%), a component of several other EOs with insecticidal activity. 
Table 5. Eucalyptus spp. essential oils with insecticidal activities.

\begin{tabular}{|c|c|c|}
\hline Eucalyptus spp. & Target Species & Reference \\
\hline E. astringens & Callosobruchus maculatus, Ephestia cautela, Ephestia kuehniella, Rhyzopertha dominica, Tribolium castaneum & {$[79,194]$} \\
\hline E. badjensis & Aedes aegypti, Haematobia irritans & {$[195,196]$} \\
\hline E. badjensis $x$ E. nitens & Aedes aegypti, Haematobia irritans & {$[195,196]$} \\
\hline E. benthamii & Sitophilus zeamais & [116] \\
\hline E. botryoides & Aedes aegypti, Haematobia irritans & {$[195,196]$} \\
\hline E. camaldulensis & $\begin{array}{l}\text { Aedes aegypti, Aedes albopictus, Atta sexdens rubropilosa, Ectomyelois ceratoniae, Ephestia cautela, } \\
\text { Ephestia kuehniella, Pediculus humanus capitis, Sitophilus zeamais, Thyrinteina arnobia }\end{array}$ & {$[63-67,72,78-80]$} \\
\hline E. cinerea & Aedes aegypti, Musca domestica, Pediculus humanus capitis & {$[63,64,81-83]$} \\
\hline E. citriodora & $\begin{array}{c}\text { Aedes aegypti, Anopheles gambia, Atta sexdens rubropilosa, Callosobruchus maculatus, } \\
\text { Lutzomyia longipalpis, Nasutitermes corniger, Pediculus humanus capitis, Sitophilus zeamais, } \\
\text { Thyrinteina arnobia, Tribolium castaneum }\end{array}$ & {$[66,67,72,82,89,90,92,95,96,103-105]$} \\
\hline E. cloeziana & Atta sexdens rubropilosa, Thyrinteina arnobia & {$[66,67]$} \\
\hline E. darlympleana & Aedes aegypti, Haematobia irritans & {$[195,196]$} \\
\hline E. dorrigoensis & Aedes aegypti, Haematobia irritans & {$[195,196]$} \\
\hline E. dundasii & Oryzaephilus surinamemsis, Rhyzopertha dominica & [197] \\
\hline E. dunnii & Aedes aegypti, Blattella germanica, Pediculus humanus capitis, Sitophilus zeamais & {$[63,64,110,116,129]$} \\
\hline E. elata & Haematobia irritans & [195] \\
\hline E. fastigata & Aedes aegypti, Haematobia irritans & {$[195,196]$} \\
\hline E. fraxinoides & Haematobia irritans & [195] \\
\hline E. floribundi & Oryzaephilus surinamemsis, Rhyzopertha dominica & [198] \\
\hline E. globulus & $\begin{array}{c}\text { Aedes aegypti, Lutzomyia longipalpis, Musca domestica, Odontotermes assamensis, Pediculus humanus } \\
\text { capitis, Sitophilus oryzae, Sitophilus zeamais, Tribolium castaneum, Tribolium confusum }\end{array}$ & {$[63,64,72,95,110-113,116,117,120-122]$} \\
\hline E. grandis & Aedes aegypti, Atta sexdens rubropilosa, Blattella germanica, Pediculus humanus capitis, Thyrinteina arnobia & {$[65-67,129,130]$} \\
\hline E. grandis $x$ E. camaldulensis & Aedes aegypti, Blattella germanica, Pediculus humanus capitis & {$[63-65,129]$} \\
\hline E. grandis $x$ E. tereticornis & Aedes aegypti, Blattella germanica, Pediculus humanus capitis & {$[63-65,129]$} \\
\hline E. gunnii & Aedes aegypti, Pediculus humanus capitis & {$[63,64,110]$} \\
\hline
\end{tabular}


Table 5. Cont

\begin{tabular}{|c|c|c|}
\hline Eucalyptus spp. & Target Species & Reference \\
\hline E. lehmannii & Callosobruchus maculatus, Ephestia cautela, Ephestia kuehniella, Rhyzopertha dominica, Tribolium castaneum & {$[79,194]$} \\
\hline E. leucoxylon & Ectomyelois ceratoniae, Ephestia cautela, Ephestia kuehniella & {$[79,80]$} \\
\hline E. maculata & Atta sexdens rubropilosa, Thyrinteina arnobia & {$[66,67]$} \\
\hline E. nobilis & Aedes aegypti, Haematobia irritans & {$[195,196]$} \\
\hline E. oblicua & Haematobia irritans & [195] \\
\hline E. polybractea & Aedes aegypti, Haematobia irritans & {$[195,196]$} \\
\hline E. radiata & Aedes aegypti, Haematobia irritans & {$[195,196]$} \\
\hline E. resinifera & Aedes aegypti, Haematobia irritans & {$[195,196]$} \\
\hline E. robertsonii & Aedes aegypti, Haematobia irritans & {$[195,196]$} \\
\hline E. rubida & Aedes aegypti, Haematobia irritans & {$[195,196]$} \\
\hline E. rudis & Ectomyelois ceratoniae, Ephestia cautela, Ephestia kuehniella & [79] \\
\hline E. saligna & $\begin{array}{c}\text { Acanthoscelides obtectus, Aedes aegypti, Atta sexdens rubropilosa, Pediculus humanus capitis, } \\
\text { Sitophilus zeamais, Sitotroga cerealella, Tribolium castaneum, Thyrinteina arnobia }\end{array}$ & {$[63,64,66,67,82,116,131,133$} \\
\hline E. sideroxylon & Aedes aegypti, Blattella germanica, Pediculus humanus capitis & {$[63,64,110,129]$} \\
\hline E. smithii & Aedes aegypti, Haematobia irritans & {$[195,196]$} \\
\hline E. staigeriana & Callosobruchus maculatus, Lutzomyia longipalpis & {$[92,95]$} \\
\hline E. tereticornis & Aedes aegypti, Anopheles gambia, Pediculus humanus capitis & {$[63-65,82,89]$} \\
\hline E. urophylla & Atta sexdens rubropilosa, Thyrinteina arnobia & {$[66,67]$} \\
\hline E. viminalis & Aedes aegypti, Blattella germanica, Pediculus humanus capitis, Sitophilus zeamais & {$[63,64,82,116,129]$} \\
\hline
\end{tabular}


The effects of EOs from E. gunnii, E. tereticornis, E. grandis, E. camaldulensis, E. dunnii, E. cinerea, E. saligna, E. sideroxylon, E. globulus ssp. globulus, E. globulus ssp. maidenii, E. viminalis and the hybrids E. grandis $\mathrm{x}$ E. tereticornis and E. grandis $x$ E. camaldulensis were tested on A. aegypti larvae. The best results were observed for E. dunnii, E. gunnii, E. tereticornis, E. camaldulensis and E. saligna which presented, respectively, $\mathrm{LC}_{50} \mathrm{~s}$ of 25.2, 21.1, 22.1, 26.8 and $22.2 \mathrm{mg} / \mathrm{L}$. In this work, a correlation between the toxicity effect and the EOs contents of 1,8-cineole and $p$-cymene was found. However, other Eucalyptus species producing EOs with high content of 1,8-cineole and low concentration of p-cymene (E. cinerea, E. globulus ssp. maidenii, E. globulus ssp. globulus, E. sideroxylon, E. viminalis, E. grandis, E. tereticornis, E. grandis, and E. camaldulensis) had a lower effect on A. aegypti (larval mortality $<50 \%$ after $24 \mathrm{~h}$ at $40 \mathrm{ppm}$ ) [63,64].The vapor of the EOs of the aforementioned Eucalyptus species were also tested on $A$. aegypti adults. The toxicity was determined as the number of knockdown mosquitoes as a function of time. The fumigation toxicity was expressed as knockdown effect time $\left(\mathrm{KT}_{50}\right)$ which varied from 4.2 to $12.0 \mathrm{~min}$. The best result was observed for E. viminalis EOs. In this case, a direct correlation was found between the EO 1,8-cineole contents and toxicity level [64].

The investigation carried out by Cheng and co-workers [78] demonstrated larvicidal activity of E. camaldulensis and E. urophylla EOs against A. aegypti and A. albopictus. The EOs from E. camaldulensis presented the best results with $\mathrm{LC}_{50}$ of 31.0 and $55.3 \mu \mathrm{g} / \mathrm{mL}$, respectively (the corresponding $\mathrm{LC}_{90}$ were 71.8 and $192.4 \mu \mathrm{g} / \mathrm{mL}$ for $A$. aegypti and A. albopictus, respectively). The larvicidal activity of individual components of E. camaldulensis EOs was also assessed. It was observed that $\alpha$-terpinene caused the highest larvicidal activity $\left(\mathrm{LC}_{50}\right.$ of $14.7 \mu \mathrm{g} / \mathrm{mL}$ and $\mathrm{LC}_{90}$ of $39.3 \mu \mathrm{g} / \mathrm{mL}$ for A. aegypti; $\mathrm{LC}_{50}$ of $25.2 \mu \mathrm{g} / \mathrm{mL}$ and $\mathrm{LC}_{90}>50.0 \mu \mathrm{g} / \mathrm{mL}$ for A. albopictus). The EOs from E. citriodora were toxic to third and fourth instar of $A$. aegypti (LC $5071.2 \mathrm{ppm}$ ) [103].

L. longipalpis is the vector of Leishmania chagasi, a protozoan species which is responsible for $90 \%$ of visceral leishmaniasis in Brazil. The effects of EOs of E. staigeriana, E. citriodora and E. globulus were evaluated on eggs, larva and adult phases of L. longipalpis. All EOs were active on the evaluated phases being E. staigeriana the most effective one, followed by E. citriodora and E. globulus [95]. Although the authors have not assessed individual essential oil components for their activities, it is worth pointing out that the EOs had citronellal as major component (71.8\%), a compound known for its insecticidal activity.

The major pest of maize S. zeamais is known to attack both standing crop and the stored cereal. Investigations on the insecticidal and repellent effects of E. dunnii, E. saligna, E. benthamii, E. globulus and E. viminalis EOs on S. zeamais were carried out. By using the contact cytotoxicity assay on filter paper, EOs from E. globulus and E. viminalis caused $100 \%$ mortality at concentrations of 0.16 and $0.23 \mu \mathrm{L} / \mathrm{cm}^{2}$ after $24 \mathrm{~h}$ of exposure, respectively. Considering this parameter, the concentration values for other EOs were as follows: $0.42 \mu \mathrm{L} / \mathrm{cm}^{2}$ for E. dunnii, $0.65 \mu \mathrm{L} / \mathrm{cm}^{2}$ for E. saligna and $2.60 \mu \mathrm{L} / \mathrm{cm}^{2}$ E. benthamii. A regression analysis allowed the calculation of $\mathrm{LC}_{50}$ values: E. viminalis $\left(0.08 \mu \mathrm{L} / \mathrm{cm}^{2}\right)$; E. globulus $\left(0.10 \mu \mathrm{L} / \mathrm{cm}^{2}\right)$; E. dunnii $\left(0.16 \mu \mathrm{L} / \mathrm{cm}^{2}\right)$; E. saligna $\left(0.25 \mu \mathrm{L} / \mathrm{cm}^{2}\right)$ and E. benthamii $\left(0.79 \mu \mathrm{L} / \mathrm{cm}^{2}\right)$. The analysis of essential oil content and mortality activity resulted in a correlation between 1,8 -cineole content and $\mathrm{LC}_{50}$. Thus, it is plausible to consider this compound responsible for the observed activity. Using the calculated $\mathrm{LC}_{50}$, it was possible to determine the repellency activity for all Eucalyptus EOs [116].

Among the components of EOs, monoterpenoids have contributed to fumigant activity against storage product pests [199], and it has been shown that they are lethal to insects by inhibiting the enzyme acetylcholinesterase activity (AChE) [200]. The repellent activity of E. saligna, E. camaldulensis, E. globulus and E. citriodora EOs were also assayed against S. zeamais. Y-shape olphatometer bioassay was utilized and the concentration tested range from 0.002 to $2 \mu \mathrm{L} / \mu \mathrm{L}$. EOs were dissolved in hexane and at the highest concentration, E. camaldulensis and E. citriodora EOs presented the best repellent activity (74.35\% and 69.15\%, respectively), followed by E. globulus (53.68\%) and E. saligna (40.5\%). The repellent activity observed for E. camaldulensis EOs was higher than that observed for the positive 
control $N$ - $N$-diethyl $m$-toluamide (DEET). Some individual constituents of the EOs were assayed and the highest repellent activity was associated with 1,8-cineole content (70.87\%) [72].

The fumigant toxicity of several EOs was evaluated on S. oryzae (also known as the rice weevil). The best activity was associated with E. globulus EOs ( $\mathrm{LD}_{50}$ of $28.9 \mu \mathrm{L} / \mathrm{L}$ of air). Individual assessment of 1,8-cineole, the major component of E. globulus EOs, revealed a $\mathrm{LD}_{50}$ of $23.5 \mu \mathrm{L} / \mathrm{L}$ of air for the fumigant toxicity [113].

The EOs from E. globulus, rich in 1,8-cineole, had their antitermite activity evaluated against O. assamensis. At the concentration of $2.5 \mathrm{mg} / \mathrm{g}$, E. globulus EOs caused $80 \%$ mortality while $70 \%$ was observed for pure 1,8-cineole [120]. These results suggest that other compounds present in the oil might be enhancing the effect of 1,8 -cineole.

P. humanus capitis (head louse) is an obligate ectoparasite responsible for the head lice infestation, also known as pediculosis capitis, nits or cooties. Several reports have described the effects of Eucalyptus EOs on P. humanus capitis. The fumigant toxicity assay was utilized to evaluate the effect of EOs from E. sideroxylon, E. globulus ssp. globulus, E. globulus ssp. maidenii, E. dunnii, and E. gunnii on head lice resistant to permetrin. Among the evaluated EOs, the most efficient ones were E. sideroxylon, E. globulus ssp. globulus and E. globulus ssp. maidenii presenting, respectively, $\mathrm{KT}_{50}$ of 24.75, 27.73, and $31.39 \mathrm{~min}$ [110]. A similar investigation conducted with EOs from E. cinerea, E. viminalis and E. saligna revealed $\mathrm{KT}_{50}$ values of 12.0, 14.9, and $17.4 \mathrm{~min}$ [82]. A comparative investigation on the effect of EOs from hybrids (E. grandis x E. camaldulensis and E. grandis x E. tereticornis) and no-hybrids (E. grandis, E. camaldulensis, and E. tereticornis) eucalyptus species on P. humanus capitis was carried out. The fumigant activity of hybrids was higher than non-hybrid ones. The observed $\mathrm{KT}_{50}$ values for the hybrid were E. grandis $\times$ E. tereticornis $(12.99 \mathrm{~min})$ and E. grandis $\times$ E. camaldulensis (13.63 $\mathrm{min})$. For the non-hybrid, the values for $\mathrm{KT}_{50}$ parameter were E. grandis (25.57 $\left.\mathrm{min}\right)$, E. camaldulensis (35.01 $\left.\mathrm{min}\right)$ and E. tereticornis (31.31 $\mathrm{min}$ ) [65].

E. citriodora leaves has been traditionally used as insecticide repellent, especially by low income families to protect themselves against mosquitoes [201].

The red flour beetle T. castaneum is a worldwide pest of stored products, particularly food grains. The EOs of E. citriodora, rich in citronellal, citronellol and isopulegol, presents repellent activity against this beetle species $(0.084 \mathrm{~mL} / \mathrm{L}$ dose repellent media after $4 \mathrm{~h}$ of exposure). The observed activity was higher than the commercial product ethyl 3-(N-acetyl- $N$-butylamino) propionate used as positive control [104].

The evaluation of fumigant activity of EOs from E. camaldulensis, E. astringens, E. leucoxylon, E. lehmannii and E. rudis against the pests of stored products E. kuehniella, E. cautella and E. ceratoniae showed that E. camaldulensis EOs present high toxicity on E. cautella and E. kuehniella $\left(\mathrm{LC}_{50}=11.07\right.$ and $26.73 \mu \mathrm{L} / \mathrm{L}$ of air, respectively). Considering E. ceratoniae, the most effective EOs were extracted from E. rudis $\left(\mathrm{LC}_{50}=31.4 \mu \mathrm{L} / \mathrm{L}\right.$ of air) [79]. In another study, the effects of E. camaldulensis and E. leucoxylon EOs on larvae and adult stages of E. ceratoniae were investigated. The EOs presented bioactivity on both stages of the insect development. For adult stage, 100\% mortality was achieved for both EOs after $120 \mathrm{~h}$ of exposure at $26.31 \mu \mathrm{L} / \mathrm{L}$ of air; at higher concentration $(131.58 \mu \mathrm{L} / \mathrm{L}$ of air) the exposure time was reduced to $48 \mathrm{~h}$. The $\mathrm{LC}_{50}$ after $24 \mathrm{~h}$ of exposure corresponded to $12.07 \mu \mathrm{L} / \mathrm{L}$ of air and $21.75 \mu \mathrm{L} / \mathrm{L}$ of air for E. camaldulensis and E. leucoxylon, respectively. Considering the larvae stage, 100\% mortality was observed at $131.58 \mu \mathrm{L} / \mathrm{L}$ of air after $264 \mathrm{~h}$ of exposure [80].

The EOs from E. tereticornis, at the concentration of $160 \mathrm{ppm}$, caused $100 \%$ mortality on the larves of Anopheles stephensi [202]. The observed insecticidal activity of E. tereticornis EOs on A. gambiae was associated to $p$-cymene and 1,8-cineole as demonstrated by the biological assays conducted with these individual components [89].

\subsection{Herbicidal Activity}

Weeds compete with crops for water, nutrients and light, and controlling their growth is of fundamental importance in modern agriculture. It is estimated that approximately $10 \%$ of all plant 
species are weeds, corresponding to approximately 30,000 species. Among them, some 1800 cause serious economic losses in crop production [203].

The observation of plant growth regulation effects caused by EOs has attracted the attention of researchers toward the possibility of utilizing these natural sources for weed control [136,204]. Such investigations are important from the viewpoint of evolution of resistance of weeds to traditional herbicides. There is a constant need for the development of weed control agents that are environmentally benign, present low toxicity to mammals, less recalcitrant, and can be applied in less quantity [205-207]. In this regard, nature has been considered an important source of compounds that can be explored to provide herbicides that can meet the aforementioned criteria $[206,208,209]$.

As shown in Table 6, several studies have been conducted on the phytotoxic effects of Eucalyptus EOs on weeds $[31,136,210,211]$. It has been demonstrated that these EOs inhibit and/or retard the germination of seeds. Effects on crop species have also been described [18].

Table 6. Eucalyptus spp. essential oils with herbicidal activities.

\begin{tabular}{ccc}
\hline Eucalyptus spp. & Target Species & Reference \\
\hline E. brockwayii & Solanum elaeagnifolium & {$[212,213]$} \\
E. camaldulensis & Amaranthus hybridus, Portulaca oleracea & {$[76]$} \\
E. citriodora & Amaranthus viridis, Cassia occidentalis, Cucumis sativus, & {$[26,54,99]$} \\
E. dundasii & Echinochloa crus-galli, Oryza sativa, Sorghum bicolor, Triticum aestivum & {$[212,213]$} \\
E. erythrocorys & Solanum elaeagnifolium & {$[158]$} \\
E. melliodora & Phalaris canariensis, Sinapis arvensis & {$[213]$} \\
E. salubris & Solanum elaeagnifolium & {$[212,213]$} \\
E. spathulata & Solanum elaeagnifolium & {$[212,213]$} \\
E. urophylla & Solanum elaeagnifolium & {$[214]$} \\
\hline
\end{tabular}

The phytotoxic effect of E. citriodora EOs collected from leaves at differents stages (juvenile and adult leaves) and fallen (senescent leaves and brown leaf litter) has been investigated on two weed species (E. crus-galli and A. viridis) and two crops (T. aestivum and O. sativa). As a general trend, the adult leaf EOs presented superior phytotoxicity compared to leaf litter EOs. In a subsequent investigation, Batish and co-workers [26] examined the phytotoxic effects of EOs extracted from decaying leaves of E. citriodora against weed species $C$. occidentalis and E. crus-galli. Also, the phytotoxicity of EOs major components, i.e., citronellal and citronellol, were also assessed. The EOs exhibited superior effect on the germination of $C$. occidentalis $\left(\mathrm{I}_{50}=1.09 \mathrm{mg} / \mathrm{mL}\right)$ compared to E. crus-galli $\left(\mathrm{I}_{50}=1.49 \mathrm{mg} / \mathrm{mL}\right)$. The EOs presented similar effects on root elongation $\left(\mathrm{I}_{50}=0.31 \mathrm{mg} / \mathrm{mL}\right.$ for C. occidentalis and $0.35 \mathrm{mg} / \mathrm{mL}$ for E. grus-galli). Comparing the effect of the major components on germination, citronellal was more effective in inhibiting the germination $\left(\mathrm{I}_{50}=0.55 \mathrm{mg} / \mathrm{mL}\right.$ and $0.14 \mathrm{mg} / \mathrm{mL}$ for $C$. occidentalis and E. grus-galli, respectively). On the contrary, citronellol caused a more pronounced effect on root elongation ( $\mathrm{I}_{50}=0.13 \mathrm{mg} / \mathrm{mL}$ and $0.09 \mathrm{mg} / \mathrm{mL}$ for C. occidentalis and E. grus-galli, respectively).

Silverleaf nightshade (S. elaeagnifolium) is a perennial and agressive weed species common in Australia. The effect of five selected Eucalyptus EOs from Australia, namely E. brockwayii, E. dundasii, E. melliodora, E. salubris and E. spathulata, on germination and root elongation of S. elaeagnifolium was evaluated. The EOs from E. salubris caused the highest (73\%) inhibitory effect on germination. This effect was superior to that observed by commercial eucalyptus EOs ( $38 \%$ of inhibition index) purchased from the market and used as positive control. In terms of root growth inhibition, E. salubris was again the most effective EOs (reduction of $84 \%$ of root elongation when applied at $10 \mu \mathrm{L} /$ dish). At the same dose, commercial eucalyptus EOs caused only $41 \%$ decrease in root length [212]. The phytotoxic effects of aqueous volatile fractions of the aforementioned EOs, i.e., the water soluble volatile fractions obtained along with the EOs (water insoluble fractions) during the steam distillation process were also assessed. It was also observed strong phytotoxic effects on germination, shoot length and root elongation of S. elaeagnifolium [213]. 
Shingh and co-workers [31] investigated the herbicidal effect of EOs produced by E. citriodora against the weed species Parthenium hysterophorus. They found that germination has been fully inhibited by the EOs (dose used $5.0 \mathrm{~nL} / \mathrm{mL}$ ). Plants of P. hysterophorus (4-week-old) were sprayed with different concentrations of EOs $(0-100 \mu \mathrm{L} / \mathrm{mL})$. A week after spraying, damage and decreased chlorophyll content and respiratory activity as the EOs concentration increased was noticed. When sprayed with concentrations up to $50 \mu \mathrm{L} / \mathrm{mL}$, plants showed recovery over time. However, when the weed species were sprayed with $75 \mu \mathrm{L} / \mathrm{mL}$ and $100 \mu \mathrm{L} / \mathrm{mL}$, plants died after two weeks. Moreover, plants sprayed with $50 \mu \mathrm{L} / \mathrm{mL}$ and concentrations higher than that were dessicated and wilted. E. citriodora EOs caused rapid electrolyte leakage at concentrations of $5-75 \mu \mathrm{L} / \mathrm{mL}$ indicating an effect on membrane integrity.

Phytotoxic effects of E. citriodora EOs on the crops S. bicolor L. (sorghum) and C. sativus L. (cucumber) have been reported. From the biological essays, an allelopathic effect was observed mainly causing germination and radicule growth inhibition of $S$. bicolor and $C$. sativus seeds. It was also observed that the increase of EOs concentration (0 to $5000 \mathrm{ppm}$ ) leads to a linear decrease in the germination as well as in the radicule length of S. bicolor [99].

\section{Concluding Remarks}

The world production and trade of EOs from several Eucalytus species is dominated by China which is the biggest producer of EOs rich in 1,8-cineole [215]. Other important producers include South Africa, Portugal, Spain, Brazil, Australia, Chile and Swaziland [45]. There are important aspects to be considered with respect to cultivation of Eucalyptus spp. aimed for production of EOs such as environmental, genetic variation and leaf type.

The majority of EOs produced by Eucalyptus are rich in monoterpenes. For medicinal purposes, the value of Eucalyptus EOs is directely associated to its content of 1,8-cineole that should be at least $70 \%$ in mass. It should be mentioned that medicinal EOs are designated in terms of 1,8-cineole content. Typical descriptions for such oils are: "Eucalyptus oil China 80\%", "Eucalyptus oil 70/75\% Spain/Portugal" and "Eucalyptus oil 80/85\% Spain/Portugal". The highest price is associated with an essential oil know as 'eucalyptol' which contains about 98\% 1,8-cineole [45,216]. In Table 7 the main Eucalyptus species that have been used for the extraction of medicinal essential oils are listed $[217,218]$.

Table 7. Eucalyptus species typically used to produce medicinal essential oils.

\begin{tabular}{ccc}
\hline Eucalyptus spp. & 1,8-Cineole (\%) & Reference \\
\hline E. camaldulensis & $80-90$ & {$[217,218]$} \\
E. cineorifolia & $40-90$ & {$[217,218]$} \\
E. dumosa & $33-70$ & {$[217,218]$} \\
E. elaeophora & $60-80$ & {$[217,218]$} \\
E. globulus & $60-85$ & {$[217,218]$} \\
E. leucoxylon & $65-75$ & {$[217,218]$} \\
E. oleosa & $45-52$ & {$[217,218]$} \\
E. polybractea & $60-93$ & {$[217,218]$} \\
E. sideroxylon & $65-75$ & {$[217,218]$} \\
E. smithii & $60-75$ & {$[217,218]$} \\
E. radiata subsp. radiata var. cineole & $70-80$ & {$[217,218]$} \\
\hline
\end{tabular}

In several cases according to the source, after extraction certain crude EOs have to be rectified to increase the percentage of 1,8-cineole required for medicinal purposes.

The EOs intended for use in perfumery are rich in citronellal, citronellol and geranyl acetate. One important source of perfumery Eucalyptus EOs is E. citriodora in which the major component is citronellal and its content should be in the range $65 \%-85 \%$. The essential oils of E. citriodora are used in whole form for fragrance purposes, usually in lower-cost soaps, perfumes and disinfectants, but their main use is as a source of citronellal for the chemical industry $[45,216,219]$. 
The term industrial oil is commonly used to describe the use of the EOs as raw materials for the isolation of their chemical constituents. The industrial EOs are characterized by high levels of phellandrene and piperitone, and mainly obtained from E. dives species [216].

As described by Coppen [220] "any attempt to accurately quantify and analyse production and consumption trends for Eucalyptus oil is fraught with difficulties. Unlike some other commodities, or some other EOs such as the citrus oils, quantitative information is not always available or accessible".

Research on EOs is of fundamental importance considering the current applications of natural extracts and EOs in the food, cosmetic, perfume, pharmaceutical, and agrochemical industries. In this review, the large chemical variability that exists among EOs from several species of Eucalyptus was demonstrated. In addition, the usefulness of those EOs in terms of their antimicrobial, insecticidal, acaricidal, and phytotoxic activity was described. In some cases, the observed biological activity of the EOs is superior to that of the products available in the market, but there is very limited research about the mechanism of action of the biological activities of such EOs. Considering all such aspects, and taking into consideration that several species of Eucalyptus are still unexplored in terms of their essential oil content and composition, we envisage that investigations in this field will continue to be active in the future. New activities will be reported for Eucalyptus EOs and further details on their mechanisms of action will also appear in the future.

Supplementary Materials: Supplementary materials can be accessed at: http://www.mdpi.com/1420-3049/21/ 12/1671/s1. Table S1. Major chemical components for Eucalyptus spp. essential oils.

Acknowledgments: We thank the Brazilian Research Agencies CNPq and FAPEMIG for financial support and research grants.

Conflicts of Interest: The authors declare no conflict of interest.

\section{References}

1. Paterson, I.; Anderson, E.A. The renaissance of natural products as drug candidates. Science 2005, 310, 451-453. [CrossRef] [PubMed]

2. Koehn, F.E.; Carter, G.T. The evolving role of natural products in drug discovery. Nat. Rev. Drug Discov. 2005, 4, 206-220. [CrossRef] [PubMed]

3. Newman, D.J.; Cragg, G.M. Natural product as sources of new drugs over the last 25 years. J. Nat. Prod. 2007, 70, 461-477. [CrossRef] [PubMed]

4. Harvey, A.L.; Edrada-Ebel, R.A.; Quinn, R.J. The re-emergence of natural products for drug discovery in the genomics era. Nat. Rev. Drug Discov. 2015, 14, 111-129. [CrossRef] [PubMed]

5. Newman, D.J.; Cragg, G.M. Natural products as sources of new drugs over the 30 years from 1981 to 2010. J. Nat. Prod. 2012, 75, 311-335. [CrossRef] [PubMed]

6. Gbenou, J.D.; Ahounou, J.F.; Akakpo, H.B.; Laleye, A.; Yayi, E.; Gbaguidi, F.; Baba-Moussa, L.; Darboux, R.; Dansou, P.; Moudachirou, M.; et al. Phytochemical composition of Cymbopogon citratus and Eucalyptus citriodora EOs and their anti-inflammatory and analgesic properties on Wisstar rats. Mol. Biol. Rep. 2013, 40, 1127-1134. [CrossRef] [PubMed]

7. Arantes, F.F.P.; Barbosa, L.C.A.; Maltha, C.R.A.; Demuner, A.J.; Costa, P.M.; Ferreira, J.R.O.; Costa-Lotufo, L.V.; Moraes, M.O.; Pessoa, C. Synthesis of novel $\alpha$-santonin derivatives as potential cytotoxic agents. Eur. J. Med. Chem. 2010, 45, 6045-6051. [CrossRef] [PubMed]

8. Paula, V.F; Barbosa, L.C.A.; Demuner, A.J.; Veloso, D.P.; Picanço, M.C. Synthesis and insecticidal activity of new amide derivates of piperine. Pest Manag. Sci. 2000, 56, 168-174. [CrossRef]

9. Barbosa, L.C.A.; Alvarenga, E.S.; Demuner, A.J.; Virtuoso, L.S.; Silva, A.A. Synthesis of new phytogrowth-inhibitory substituted aryl-p-benzoquinones. Chem. Biodivers. 2006, 3, 553-567. [CrossRef] [PubMed]

10. Cantrell, C.L.; Dayan, F.E.; Duke, S.O. Natural Products as sources of new pesticides. J. Nat. Prod. 2012, 75, 1231-1242. [CrossRef] [PubMed]

11. Copping, L.G.; Duke, S.O. Natural products that have been used commercially as crop protection agents. Pest Manag. Sci. 2007, 63, 524-554. [CrossRef] [PubMed] 
12. Gerwick, B.C.; Sparks, T.C. Natural products for pest control: An analysis of their role, value and future. Pest Manag. Sci. 2014, 70, 1169-1185. [CrossRef] [PubMed]

13. Lima, L.S.; Barbosa, L.C.A.; Alvarenga, E.S.; Demuner, A.J.; Silva, A.A. Synthesis and phytotoxicity evaluation of substituted para-benzoquinones. Aust. J. Chem. 2003, 36, 625-630. [CrossRef]

14. Kalemba, D.; Kunicka, A. Antibacterial and antifungal properties of EOs. Curr. Med. Chem. 2003, 10, 813-829. [CrossRef] [PubMed]

15. Bakkali, F.; Averbeck, S.; Averbeck, D.; Idaomar, M. Biological effects of EOs-A review. Food Chem. Toxicol. 2008, 46, 446-475. [CrossRef] [PubMed]

16. Silva, C.J.; Barbosa, L.C.A.; Demuner, A.J.; Montanari, R.M.; Francino, D.; Meira, R.M.S.A.; Souza, A.O. Chemical composition and histochemistry of Sphagneticola trilobata essential oil. Rev. Bras. Farmacogn. 2012, 22, 482-489. [CrossRef]

17. Gilles, M.; Zhao, J.; An, M.; Agboola, S. Chemical composition and antimicrobial properties of EOs of three Australian Eucalyptus species. Food Chem. 2010, 119, 731-737. [CrossRef]

18. Ens, E.J.; Bermner, J.B.; French, K.; Korth, J. Identification of volatile compounds released by roots of an invasive plant, bitou bush (Chrysanthemoides monilifera spp. rotundata), and their inhibition of native seedling growth. Biol. Invasions 2009, 11, 275-287. [CrossRef]

19. Passos, J.L.; Meira, R.M.S.A.; Barbosa, L.C.A.; Barreto, R.W. Foliar anatomy of the species Lantana camara and L. radula (Verbenaceae). Planta Daninha 2009, 27, 689-700. [CrossRef]

20. Sefidkon, F.; Assareh, M.H.; Abravesh, Z.; Barazandeh, M.M. Chemical composition of the EOs of four cultivated Eucalyptus species in Iran as medicinal plants (E. microtheca, E. spathulata, E. largiflorens and E. torquata). Iran. J. Pharm. Res. 2007, 6, 135-140.

21. Si, W.; Gong, J.; Tsao, R.; Zhou, T.; Yu, H.; Poppe, C.; Johnson, R.; Du, Z. Antimicrobial activity of EOs and structurally related synthetic food additives towards selected pathogenic and beneficial gut bacteria. J. Appl. Microbiol. 2006, 100, 296-305. [CrossRef] [PubMed]

22. Langenheim, J.H. Higher plant terpenoids: Phytocentric overview of their ecological roles. J. Chem. Ecol. 1994, 20, 1223-1280. [CrossRef] [PubMed]

23. Holopainen, J.L. Multiple functions of inducible plant volatiles. Trends Plant Sci. 2004, 9, 529-533. [CrossRef] [PubMed]

24. Penuelas, J.; Llusià, J. Plant VOC emissions: Making use of the unavoidable. Trends Ecol. Evol. 2004, 19, 402-404. [CrossRef] [PubMed]

25. Barbosa, L.C.A.; Demuner, A.J.; Dumont, A.C.; Paula, V.F.; Ismail, F.M.D. Seasonal variation in the composition of volatile oils from Schinus terebinthifolius Raddi. Quim. Nova 2007, 30, 1959-1965. [CrossRef]

26. Batish, D.R.; Singh, H.P.; Setia, N.; Kaur, S.; Kohli, R.K. Chemical composition and inhibitory activity of essential oil from decaying leaves of Eucalyptus citriodora. Z. Naturforsch. 2006, 61, 52-56. [CrossRef]

27. Angelini, L.G.; Carpanese, G.; Cioni, P.L.; Morelli, I.; Macchia, M.; Flamni, G. EOs from Mediterranean Lamiaceae as weed germination inhibitors. J. Agric. Food Chem. 2003, 51, 6158-6164. [CrossRef] [PubMed]

28. Barney, J.N.; Hay, A.G.; Weston, L.A. Isolation and characterization of volatiles from mugwort. J. Chem. Ecol. 2005, 31, 247-265. [CrossRef] [PubMed]

29. Dudai, N.; Mayer, A.M.; Putievsky, E.; Lerner, H.R. Essential oil as allelochemicals and their potential use as bioherbicides. J. Chem. Ecol. 1999, 25, 1079-1089. [CrossRef]

30. Tworkoski, T. Herbicide effects of essential oil. Weed Sci. 2002, 50, 425-431. [CrossRef]

31. Singh, H.P.; Batish, D.R.; Setia, N.; Kohli, R.K. Herbicidal activity of volatile oils from Eucalyptus citriodora against Parthenium hysterophorus. Ann. Appl. Biol. 2005, 146, 89-94. [CrossRef]

32. Isman, M.B. Plant EOs for pest and disease management. Crop Prot. 2000, 19, 603-608. [CrossRef]

33. Montanari, R.M.; Barbosa, L.C.A.; Demuner, A.J.; Silva, C.J.; Carvalho, L.S.; Andrade, N.J. Chemical composition and antibacterial activity of essential oils from Verbenaceae species: Alternative sources of (E)-caryophyllene and germacrene-D. Quim. Nova 2011, 34, 1550-1555. [CrossRef]

34. Nascimento, J.C.; Barbosa, L.C.A.; Paula, V.F.; David, J.M.; Fontana, R.; Silva, L.A.M.; França, R.S. Chemical composition and antimicrobial activity of essential oils of Ocimum canum Sims. and Ocimum selloi Benth. Ann. Acad. Bras. Cienc. 2011, 83, 787-799. [CrossRef]

35. Demuner, A.J.; Barbosa, L.C.A.; Magalhães, C.G.; Silva, C.J.; Maltha, C.R.A.; Pinheiro, A.L. Seasonal variation in the chemical composition and antimicrobial activity of volatile oils of three species of Leptospermum (Myrtaceae) grown in Brazil. Molecules 2011, 16, 1181-1191. [CrossRef] [PubMed] 
36. Silva, C.J.; Barbosa, L.C.A.; Demuner, A.J.; Montanari, R.M.; Pinheiro, A.L.; Dias, I.; Andrade, N.J. Chemical composition and antibacterial activities from the essential oils of Myrtaceae species planted in Brazil. Quím. Nova 2010, 33, 104-108. [CrossRef]

37. Martins, F.T.; Doriguetto, A.C.; Souza, T.C.; Souza, K.R.D.; Santos, M.H.; Moreira, M.E.C.; Barbosa, L.C.A. Composition, and anti-inflammatory and antioxidant activities of the volatile oil from the fruit peel of Garcinia brasiliensis. Chem. Biodivers. 2008, 5, 251-258. [CrossRef] [PubMed]

38. Burt, S. EOs: Their antibacterial properties and potential applications in foods-A review. Int. J. Food Microbiol. 2004, 94, 223-253. [CrossRef] [PubMed]

39. Stefanakis, M.K.; Touloupakis, E.; Anastasopoulos, E.; Ghanotakis, D.; Katerinopoulos, H.E.; Makridis, P. Antibacterial activity of EOs from plants of the genus Origanum. Food Control 2013, 34, 539-546. [CrossRef]

40. Hill, K.D.; Johnson, L.A.S. Systematic studies in the eucalypts. 7. A revision of the bloodwoods, genus Corymbia (Myrtaceae). Telopea 1995, 6, 185-504. [CrossRef]

41. Pereira, V.; Dias, C.; Vasconcelos, M.C.; Rosa, E.; Saavedra, M.J. Antibacterial activity and synergistic effects between Eucalyptus globulus leaf residues (EOs and extracts) and antibiotics against several isolates of respiratory tract infections (Pseudomonas aeruginosa). Ind. Crops Prod. 2014, 52, 1-7. [CrossRef]

42. Bello, M.O.; Olabanji, I.O.; Ibrahim, A.O.; Yekeen, T.A.; Oboh, L.M. Nutraceuticals in leaves of Eucalyptus citriodora and Eucalyptus camandulensis. Food Sci. 2013, 62, 17873-17876.

43. Tyagi, A.K.; Malik, A. Antimicrobial potential and chemical composition of Eucalyptus globulus oil in liquid and vapour phase against food spoilage microorganisms. Food Chem. 2011, 126, 228-235. [CrossRef]

44. Araujo, F.O.L.; Rietzler, A.C.; Duarte, L.P.; Silva, G.D.F.; Carazza, F.; Filho, S.A.V. Constituents químicos e efeito ecotoxicológico do óleo volátil de folhas de Eucalyptus urograndis (Mirtaceae). Quím. Nova 2010, 33, 1510-1513. [CrossRef]

45. Bizzo, H.R.; Hovell, A.M.C.; Rezende, C.M. Óleos essenciais no Brazil: Aspectos gerais, desenvolvimento e perspectivas. Quím. Nova 2009, 32, 588-594. [CrossRef]

46. Pino, J.A.; Marbot, R.; Quert, R.; Garcia, H. Study of EOs of Eucalyptus resinifera Smith, E. tereticornis Smith and Corymbia maculata (Hook.) K.D. Hill \& L.A.S. Johnson, grown in Cuba. Flavour Frag. J. 2002, 17, 1-4.

47. Vuong, Q.V.; Chalmers, A.C.; Bhuyan, D.J.; Bowyer, M.C.; Scarlett, C.J. Botanical, phytochemical, and anticancer properties of the Eucalyptus species. Chem. Biodivers. 2015, 12, 907-924. [CrossRef] [PubMed]

48. Zhang, J.; An, M.; Wu, H.; Stanton, R.; Lemerle, D. Chemistry and bioactivity of Eucalyptus essential oils. Allelopathy J. 2010, 25, 313-330.

49. Elaissi, A.; Salah, K.H.; Mabrouk, S.; Larbi, K.M.; Chemli, R.; Harzallah-Skhiri, F. Antibacterial activity and chemical composition of 20 Eucalyptus species' EOs. Food Chem. 2011, 129, 1427-1434. [CrossRef]

50. Watanabe, K.; Shono, Y.; Kakimizu, A.; Okada, A.; Matsuo, N.; Satoh, A.; Nishimura, H. New mosquito repellent from Eucalyptus camaldulensis. J. Agric. Food Chem. 1993, 41, 2164-2166. [CrossRef]

51. Li, H.; Madden, J.L.; Potts, B.M. Variation in volatile leaf oils of the Tasmanian Eucalyptus species I. Subgenus Monocalyptus. Biochem. Syst. Ecol. 1995, 23, 299-318. [CrossRef]

52. Li, H.; Madden, J.L.; Potts, B.M. Variation in volatile leaf oils of the Tasmanian Eucalyptus species II. Subgenus Symphyomyrtus. Biochem. Syst. Ecol. 1996, 24, 547-569. [CrossRef]

53. Cimanga, K.; Kambu, K.; Tona, L.; Apers, S.; de Bruyne, T.; Hermans, N.; Totté, J.; Pieters, L.; Vlietinck, A.J. Correlation between chemical composition and antibacterial activity of EOs of some aromatic medicinal plants growing in the Democratic Republic of the Congo. J. Ethnopharmacol. 2002, 79, 213-220. [CrossRef]

54. Batish, D.R.; Singh, H.P.; Setia, N.; Kaur, S.; Kohli, R.K. Chemical composition and phytotoxicity of volatile essential oil from intact and fallen leaves of Eucalyptus citriodora. Z. Naturforsch. 2006, 61, 465-471. [CrossRef]

55. Quereshi, S.; Upadhyay, A.; Singh, R.; Khan, N.A.; Mani, A.; Patel, J. GC Analysis of EOs, TLC Profiling of Pigments and DNA Extraction from Eucalyptus Species. Curr. Bot. 2011, 2, 23-26.

56. Silva, F.; Santos, R.H.S.; Andrade, N.J.; Barbosa, L.C.A.; Casali, V.W.D.; Lima, R.R.; Passarinho, R.V.M. Basil conservation affected by cropping season, harvest time and storage period. Pesq. Agropec. Bras. 2005, 40, 323-328. [CrossRef]

57. Barbosa, F.F.; Barbosa, L.C.A.; Melo, E.C.; Botelho, F.M.; Santos, R.H.S. Influência da temperatura do ar de secagem sobre o teor e a composição química do óleo essencial de Lippia alba (Mill) N. E. Brown. Quím. Nova 2006, 29, 1221-1225. [CrossRef]

58. Lemos, D.R.H.; Melo, E.C.; Rocha, R.P.; Barbosa, L.C.A.; Pinheiro, A.L. Influence of drying air temperature on the chemical composition of the essential oil of melaleuca. Eng. Agric. 2012, 20, 5-11. [CrossRef] 
59. Pimentel, F.A.; Cardoso, M.G.; Guimarães, L.G.L.; Queiroz, F.; Barbosa, L.C.A.; Morais, A.R.; Nelson, D.L.; Andrade, M.A.; Zacaroni, L.M.; Pimentel, S.M.N.P. Extracts from the leaves of Piper piscatorum (Trel. Yunc.) obtained by supercritical extraction of with $\mathrm{CO}_{2}$, employing ethanol and methanol as co-solvents. Ind. Crops Prod. 2013, 43, 490-495. [CrossRef]

60. Bignell, C.M.; Dunlop, P.J.; Brophy, J.J.; Fookes, C.J.R. Volatile leaf oils of some South-western and Southern Australian species of the genus Eucalyptus (Series I). Part XIV. Subgenus Monocalyptus. Flavour Frag. J. 1997, 12, 177-183. [CrossRef]

61. Gonçalves, L.A.; Barbosa, L.C.A.; Azevedo, A.A.; Casali, V.W.D.; Nascimento, E.A. Produção e composição do óleo essencial de alfavaquinha (Ocimim selloi Benth.) em resposta a dois níveis de radiação solar. Rev. Bras. Plantas Med. 2003, 6, 8-14.

62. Silva, A.F.; Barbosa, L.C.A.; Silva, E.A.M.; Casali, V.W.D.; Nascimento, E.A. Composição química do óleo essencial de Hyptis suaveolens (L.) Poit. (Lamiaceae). Rev. Bras. Plantas Med. 2003, 6, 1-7.

63. Lucia, A.; Licastro, S.; Zerba, E.; Masuh, H. Yield, chemical composition, and bioactivity of EOs from 12 species of Eucalyptus on Aedes aegypti larvae. Entomol. Exp. Appl. 2008, 129, 107-114. [CrossRef]

64. Lucia, A.; Licastro, S.; Zerba, E.; Gonzalez, A.P.; Masuh, H. Sensitivity of Aedes aegypti adults (Diptera: Culicidae) to the vapors of Eucalyptus EOs. Bioresour. Technol. 2009, 100, 6083-6087. [CrossRef] [PubMed]

65. Toloza, A.; Lucia, A.; Zerba, E.; Masuh, H.; Picollo, M.I. Interspecific hybridization of Eucalyptus as a potential tool to improve the bioactivity of EOs against permethrin-resistant head lice from Argentina. Bioresour. Technol. 2008, 99, 7341-7347. [CrossRef] [PubMed]

66. Batista-Pereira, L.G.; Fernandes, J.B.; Silva, M.F.G.F.; Vieira, P.C.; Bueno, O.C.; Correêa, A.G. Electrophysiological responses of Atta sexdens rubropilosa workers to EOs of Eucalyptus and its chemical composition. Z. Naturforsch. 2006, 61, 749-755.

67. Batista-Pereira, L.G.; Fernandes, J.B.; Correa, A.G.; da Silva, M.F.G.F.; Vieira, P.C. Electrophysiological responses of Eucalyptus brown looper Thyrinteina arnobia to EOs of seven Eucalyptus species. J. Braz. Chem. Soc. 2006, 17, 555-561. [CrossRef]

68. Filomeno, C.A.; Barbosa, L.C.A.; Pereira, J.L.; Pinheiro, A.L.; Fidencio, P.H.; Montanari, R.M. The chemical diversity of Eucalyptus spp. essential oils from plants grown in Brazil. Chem. Biodivers. 2008. [CrossRef] [PubMed]

69. Salem, M.Z.M.; Zidan, Y.E.; Mansour, M.M.A.; El Hadidi, N.M.N.; Abo Elgat, W.A.A. Antifungal activities of two essential oils used in the treatment of three commercial woods deteriorated by five common mold fungi. Int. Biodeterior. Biodegrad. 2016, 106, 88-96. [CrossRef]

70. Debbarma, J.; Kishore, P.; Nayak, B.B.; Kannuchamy, N.; Gudipati, V. Antibacterial activity of ginger, Eucalyptus and sweet orange peel EOs on fish-borne bacteria. J. Food Process. Preserv. 2013, 37, 1022-1030.

71. Ghasemi, V.; Moharramipour, S.; Tahmasbi, G. Biological activity of some plant EOs against Varroa destructor (Acari: Varroidae), an ectoparasitic mite of Apis mellifera (Hymenoptera: Apidae). Exp. Appl. Acarol. 2011, 55, 147-154. [CrossRef] [PubMed]

72. Karemu, C.K.; Ndung'u, M.W.; Githua, M. Repellent effects of EOs from selected Eucalyptus species and their major constituents against Sitophilus zeamais (Coleoptera: Curculionidae). Int. J. Trop. Insect Sci. 2013, 33, 188-194. [CrossRef]

73. Oyedeji, A.O.; Ekundayo, O.; Olawore, O.N.; Adeniyi, B.A.; Koenig, W.A. Antimicrobial activity of the EOs of five Eucalyptus species growing in Nigeria. Fitoterapia 1999, 70, 526-528. [CrossRef]

74. Akin, M.; Aktumsek, A.; Nostro, A. Antibacterial activity and composition of the EOs of Eucalyptus camaldulensis Dehn. and Myrtus communis L. growing in Northern Cyprus. Afr. J. Biotechnol. 2010, 9, 531-535.

75. Ghaffar, A.; Yameen, M.; Kiran, S.; Kamal, S.; Jalal, F.; Munir, B.; Saleem, S.; Rafiq, N.; Ahmad, A.; Saba, I.; et al. Chemical composition and in-vitro evaluation of the antimicrobial and antioxidant activities of essential oils extracted from seven Eucalyptus species. Molecules 2015, 20, 20487-20498. [CrossRef] [PubMed]

76. Verdeguer, M.; Blazquez, M.A.; Boira, H. Phytotoxic effects of Lantana camara, Eucalyptus camaldulensis and Eriocephalus africanus EOs in weeds of Mediterranean summer crops. Biochem. Syst. Ecol. 2009, 37, 362-369. [CrossRef]

77. Su, Y.C.; Ho, C.L.; Wang, E.I.; Chang, S.T. Antifungal activities and chemical compositions of EOs from leaves of four Eucalyptus. Taiwan J. Sci. 2006, 21, 49-61.

78. Cheng, S.S.; Huang, C.G.; Chen, Y.J.; Yu, J.J.; Chen, W.J.; Chang, S.T. Chemical compositions and larvicidal activities of leaf EOs from two Eucalyptus species. Bioresour. Technol. 2009, 100, 452-456. [CrossRef] [PubMed] 
79. Jemaa, J.M.B.; Haouel, S.; Bouaziz, M.; Khouja, M.L. Seasonal variations in chemical composition and fumigant activity of five Eucalyptus EOs against three moth pests of stored dates in Tunisia. J. Stored Prod. Res. 2012, 48, 61-67. [CrossRef]

80. Jemaa, J.M.B.; Haouel, S.; Khouja, M.L. Efficacy of Eucalyptus EOs fumigant control against Ectomyelois ceratoniae (Lepidoptera: Pyralidae) under various space occupation conditions. J. Stored Prod. Res. 2013, 53, 67-71. [CrossRef]

81. Rossi, Y.E.; Palacios, S.M. Insecticidal toxicity of Eucalyptus cinerea essential oil and 1,8-cineole against Musca domestica and possible uses according to the metabolic response of flies. Ind. Crops Prod. 2015, 63, 133-137. [CrossRef]

82. Toloza, A.C.; Zygadlo, J.; Mougabure, C.G.; Biurrun, F.; Zerba, E.; Picollo, M.I. Fumigant and repellent properties of EOs and component compounds against permethrin-resistant Pediculus humanus capitis (Anoplura: Pediculidae) from Argentina. J. Med. Entomol. 2006, 43, 889-895. [CrossRef]

83. Palacios, S.M.; Bertoni, A.; Rossi, T.; Santander, R.; Urzúa, A. Efficacy of EOs from edible plants as insecticides against the house fly, Musca Domestica L. Molecules 2009, 14, 1938-1947. [CrossRef] [PubMed]

84. Silva, S.M.; Abe, S.Y.; Murakami, F.S.; Frensch, G.; Marques, F.A.; Nakashima, T. EOs from different plant parts of Eucalyptus cinerea F. Muell. ex Benth. (Myrtaceae) as a source of 1,8-cineole and their bioactivities. Pharmaceuticals 2011, 4, 1535-1550. [CrossRef] [PubMed]

85. Franco, J.; Nakashima, T.; Franco, L.; Boller, C. Composição química e atividade antimicrobiana in vitro do óleo essencial de Eucalyptus cinerea F. Mull. Ex Benth., Myrtaceae, extraído em diferentes intervalos de tempo. Rev. Bras. Farmacogn. 2005, 15, 191-194. [CrossRef]

86. Sebei, K.; Sakouhi, F.; Herchi, W.; Khouja, M.L.; Boukhchina, S. Chemical composition and antibacterial activities of seven Eucalyptus species EOs leaves. Biol. Res. 2015, 48, 7. [CrossRef] [PubMed]

87. Elaissi, A.; Marzouki, H.; Medini, H.; Khouja, M.L.; Farhat, F.; Lynene, F.; Harzallah-Skhiri, F.; Chemli, R. Variation in volatile leaf oils of 13 Eucalyptus species harvested from Souinet Arboreta (Tunisia). Chem. Biodivers. 2010, 7, 909-921. [CrossRef] [PubMed]

88. Lee, Y.-S.; Kim, J.; Shin, S.-C.; Lee, S.-G.; Park, I.-K. Antifungal activity of Myrtaceae EOs and their components against three phytopathogenic fungi. Flavour Fragr. J. 2008, 23, 23-28. [CrossRef]

89. Bossou, A.D.; Mangelinckx, S.; Yedomonhan, H.; Boko, P.M.; Akogbeto, M.C.; Kimpe, N.; Avlessi, F.; Sohounhloue, D.C.K. Chemical composition and insecticidal activity of plant EOs from Benin against Anopheles gambiae (Giles). Parasit. Vectors 2013, 6, 337. [CrossRef] [PubMed]

90. Bossou, A.D.; Ahoussi, E.; Ruysbergh, E.; Adams, A.; Smagghe, G.; De Kimpe, N.; Avlessi, F.; Sohounhloue, D.C.K.; Mangelinckx, S. Characterization of volatile compounds from three Cymbopogon species and Eucalyptus citriodora from Benin and their insecticidal activities against Tribolium castaneum. Ind. Crops Prod. 2015, 76, 306-317. [CrossRef]

91. Chagas, A.C.S.; Passos, W.M.; Prates, H.T.; Leitem, R.C.; Furlong, J.; Fortes, I.C.P. Acaricide effect of Eucalyptus spp. EOs and concentrated emulsion on Boophilus microplus. Braz. J. Vet. Res. Anim. Sci. 2002, 39, 247-253.

92. Gusmao, N.M.S.; Oliveira, J.V.; Navarro, D.M.A.F.; Dutra, K.A.; Silva, W.A.; Wanderley, M.J.A. Contact and fumigant toxicity and repellency of Eucalyptus citriodora Hook., Eucalyptus staigeriana F., Cymbopogon winterianus Jowitt and Foeniculum vulgare Mill. EOs in the management of Callosobruchus maculatus (FABR.) (Coleoptera: Chrysomelidae, Bruchinae). J. Stored Prod. Res. 2013, 54, 41-47.

93. Estanislau, A.A.; Barros, F.A.S.; Peña, A.P.; Santos, S.C.; Ferri, P.H.; Paula, J.R. Composição química e atividade antibacteriana dos óleos essenciais de cinco espécies de Eucalyptus cultivadas em Goiás. Rev. Bras. Farmacogn. 2001, 11, 95-100.

94. Macedo, I.T.F.; Bevilaqua, C.M.L.; Oliveira, L.M.B.; Camurça-Vasconcelos, A.L.F.; Vieira, L.S.; Amóra, S.S.A. Evaluation of Eucalyptus citriodora essential oil on goat gastrointestinal nematodes. Rev. Bras. Parasitol. Vet. 2011, 20, 223-227. [CrossRef] [PubMed]

95. Maciel, M.V.; Morais, S.M.; Bevilaqua, C.M.L.; Silva, R.A.; Barros, R.S.; Sousa, R.N.; Sousa, L.C.; Brito, E.S.; Souza-Neto, M.A. Chemical composition of Eucalyptus spp. EOs and their insecticidal effects on Lutzomyria longipalpis. Vet. Parasitol. 2010, 167, 1-7. [CrossRef] [PubMed]

96. Lima, J.K.A.; Albuquerque, E.L.D.; Santos, A.C.C.; Oliveira, A.P.; Araujo, A.P.A.; Blank, A.F.; Arrigoni-Blank, M.F.; Alves, P.B.; Santos, D.A.; Bacci, L. Biotoxicity of some plant EOs against the termite Nasutitermes corniger (Isoptera: Termitidae). Ind. Crops Prod. 2013, 47, 246-251. [CrossRef] 
97. Ribeiro, J.C.; Ribeiro, W.L.C.; Camurça-Vasconcelos, A.L.F.; Macedo, I.T.F.; Santos, J.M.L.; Paula, H.C.B.; Araujo Filho, J.V.; Magalhães, R.D.; Bevilaqua, C.M.L. Efficacy of free and nanoencapsulated Eucalyptus citriodora EOs on sheep gastrointestinal nematodes andtoxicity for mice. Vet. Parasitol. 2014, 204, 243-248. [CrossRef] [PubMed]

98. Aguiar, R.W.S.; Ootani, M.A.; Ascencio, S.D.; Ferreira, T.P.S.; Santos, M.M.; Santos, G.R. Fumigant antifungal activity of Corymbia citriodora and Cymbopogon nardus EOs and citronellal against three fungal species. Sci. World J. 2014, 2014, 149-168. [CrossRef] [PubMed]

99. Tomaz, M.A.; Costa, A.V.; Rodrigues, W.N.; Pinheiro, P.F.; Parreira, L.A.; Rinaldo, D.; Queiroz, V.T. Chemical composition and allelopathic activity of the Eucalyptus essential oil. Biosci. J. 2014, 30, 475-483.

100. Han, J.; Choi, B.R.; Lee, S.G.; Kim, S.I.; Ahn, Y.J. Toxicity of plant EOs to acaricide-susceptible and -resistant Tetranychus urticae (Acari: Tetranychidae) and Neoseiulus californicus (Acari: Phytoseiidae). J. Econ. Entomol. 2010, 103, 1293-1298. [CrossRef] [PubMed]

101. Han, J.; Kim, S.I.; Choi, B.R.; Lee, S.G.; Ahn, Y.J. Fumigant toxicity of lemon Eucalyptus oil constituents to acaricide-susceptible and acaricide-resistant Tetranychus urticae. Pest Manag. Sci. 2011, 67, 1583-1588. [CrossRef] [PubMed]

102. George, D.R.; Masic, D.; Sparagano, O.A.E.; Guy, J.H. Variation in chemical composition and acaricidal activity against Dermanyssus gallinae of four Eucalyptus EOs. Exp. Appl. Acarol. 2009, 48, 43-50. [CrossRef] [PubMed]

103. Vera, S.S.; Zambrano, D.F.; Méndez-Sanchez, S.C.; Rodríguez-Sanabria, F.; Stashenko, E.E.; Luna, J.E.D. EOs with insecticidal activity against larvae of Aedes aegypti (Diptera: Culicidae). Parasitol. Res. 2014, 113, 2647-2654. [CrossRef] [PubMed]

104. Olivero-Verbel, J.; Nerio, L.S.; Stashenko, E.E. Bioactivity against Tribolium castaneum Herbst (Coleoptera: Tenebrionidae) of Cymbopogon citratus and Eucalyptus citriodora EOs grown in Colombia. Pest Manag. Sci. 2010, 66, 664-668. [PubMed]

105. Olivero-Verbel, J.; Tirado-Ballestas, I.; Caballero-Gallardo, K.; Stashenko, E.E. EOs applied to the food act as repellents toward Tribolium castaneum. J. Stored Prod. Res. 2013, 55, 145-147. [CrossRef]

106. Mulyaningsih, S.; Sporer, F.; Reichling, J.; Wink, M. Antibacterial activity of EOs from Eucalyptus and of selected components against multidrug-resistant bacterial pathogens. Pharm. Biol. 2011, 49, 893-899. [CrossRef] [PubMed]

107. Lee, S.O.; Choi, G.J.; Jang, K.S.; Lim, H.K.; Cho, K.Y.; Kim, J. Antifungal activity of five plant EOs as fumigant against postharvest and soilborne plant pathogenic fungi. Plant Pathol. J. 2007, 23, 97-102. [CrossRef]

108. Elaissi, A.; Medini, H.; Simmonds, M.; Lynen, F.; Farhat, F.; Chemli, R.; Harzallah-Skhiri, F.; Khouja, M.L. Variation in volatile leaf oils of seven Eucalyptus species harvested from Zerniza Arboreta (Tunisia). Chem. Biodivers. 2011, 8, 362-372. [CrossRef] [PubMed]

109. Harkat-Madouri, L.; Asma, B.; Madani, K.; Said, Z.B.S.; Rigou, P.; Grenier, D.; Allalou, H.; Remini, H.; Adjaoud, A.; Boulekbache-Makhlouf, L. Chemical composition, antibacterial and antioxidant activities ofessential oil of Eucalyptus globulus from Algeria. Ind. Crops Prod. 2015, 78, 148-153. [CrossRef]

110. Toloza, A.C.; Lucia, A.; Zerba, E.; Masuh, H.; Picollo, M.I. Eucalyptus essential oil toxicity against permethrin-resistant Pediculus humanus capitis (Phthiraptera: Pediculidae). Parasitol. Res. 2010, 106, 409-414. [CrossRef] [PubMed]

111. Russo, S.; Cabrera, N.; Chludil, H.; Yaber-Grass, M.; Leicach, S. Insecticidal activity of young and mature leaves essential oil from Eucalyptus globulus Labill. against Tribolium confusum Jacquelin du Val (Coleoptera: Tenebrionidae). Chil. J. Agric. Res. 2015, 75, 375-379. [CrossRef]

112. Yang, Y.; Choi, H.; Choi, W.; Clark, J.M.; Ahn, Y. Ovicidal and adulticidal activity of Eucalyptus globulus leaf oil terpenoids against Pediculus humanus capitis (Anoplura: Pediculidae). J. Agric. Food Chem. 2004, 52, 2507-2511. [CrossRef] [PubMed]

113. Lee, B.; Choi, W.; Lee, S.; Park, B. Fumigant toxicity of EOs and their constituent compounds towards the rice weevil, Sitophilus oryzae (L.). Crop Prot. 2001, 20, 317-320. [CrossRef]

114. Vilela, G.R.; Almeida, G.S.; D'Arce, M.A.B.R.; Moraes, M.H.D.; Brito, J.O.; Silva, M.F.G.F.; Silva, S.C.; Piedade, S.M.S.; Calori-Domingues, M.A.; Gloria, E.M. Activity of essential oil and its major compound, 1,8-cineole, from Eucalyptus globulus Labill., against the storage fungi Aspergillus flavus Link and Aspergillus parasiticus Speare. J. Stored Prod. Res. 2009, 45, 108-111. [CrossRef] 
115. Macedo, I.T.F.; Bevilaqua, C.M.L.; Oliveira, L.M.B.; Camurça-Vasconcelos, A.L.F.; Vieira, L.S.; Oliveira, F.R.; Queiroz-Junior, E.M.; Portela, B.G.; Barros, R.S.; Chagas, A.C.S. Ovicidal and larvicidal activity in vitro of Eucalyptus globulus EOs on Haemonchus contortus. Rev. Bras. Parasitol. Vet. 2009, 18, 62-66. [CrossRef] [PubMed]

116. Mossi, A.J.; Astolfi, V.; Kubiak, G.; Lerin, L.; Zanella, C.; Toniazzo, G.; Oliveira, D.; Treichel, H.; Devilla, I.A.; Cansiana, R.; Restello, R. Insecticidal and repellency activity of essential oil of Eucalyptus sp. against Sitophilus zeamais Motschulsky (Coleoptera, Curculionidae). J. Sci. Food Agric. 2011, 91, 273-277. [CrossRef] [PubMed]

117. Yones, D.A.; Bakir, H.Y.; Bayoumi, S.A.L. Chemical composition and efficacy of some selected plant oils against Pediculus humanus capitis in vitro. Parasitol. Res. 2016, 115, 3209-3218. [CrossRef] [PubMed]

118. Mekonnen, A.; Yitayew, B.; Tesema, A.; Taddese, S. In Vitro Antimicrobial activity of essential oil of Thymus schimperi, Matricaria chamomilla, Eucalyptus globulus, and Rosmarinus officinalis. Int. J. Microbiol. 2016, 2016, 9545693. [CrossRef] [PubMed]

119. Gupta, A.; Sharma, S.; Naik, S.N. Biopesticidal value of selected EOs against pathogenic fungus, termites, and nematodes. Int. Biodeterior. Biodegard. 2011, 65, 703-707. [CrossRef]

120. Pandey, A.; Chattopadhyay, P.; Banerjee, S.; Pakshirajan, K.; Singh, L. Antitermitic activity of plant EOs and their major constituents against termite Odontotermes assamensis Holmgren (Isoptera: Termitidae) of North East India. Int. Biodeterior. Biodegrad. 2012, 75, 63-67. [CrossRef]

121. Pant, M.; Dubey, S.; Patanjali, P.K.; Naik, S.N.; Sharma, S. Insecticidal activity of Eucalyptus oil nanoemulsion with karanja and jatropha aqueous filtrates. Int. Biodeterior. Biodegard. 2014, 91, 119-127. [CrossRef]

122. Kumar, P.; Mishra, S.; Malik, A.; Satya, S. Compositional analysis and insecticidal activity of Eucalyptus globulus (family: Myrtaceae) essential oil against housefly (Musca domestica). Acta Trop. 2012, 122, 212-218. [CrossRef] [PubMed]

123. Golestani, M.R.; Rad, M.; Bassami, M.; Afkhami-Goli, A. Analysis and evaluation of antibacterial effects of new herbal formulas, AP-001 and AP-002, against Escherichia coli O157:H7. Life Sci. 2015, 135, 22-26. [CrossRef] [PubMed]

124. Tohidpour, A.; Sattari, M.; Omidbaigi, R.; Yadegar, A.; Nazemi, J. Antibacterial effect of EOs from two medicinal plants against Methicillin-resistant Staphylococcus aureus (MRSA). Phytomedicine 2010, 17, 142-145. [CrossRef] [PubMed]

125. Fratini, F.; Casella, S.; Leonardi, M.; Pisseri, F.; Ebani, V.V.; Pistelli, L.; Pistelli, L. Antibacterial activity of EOs, their blends and mixtures of their main constituents against some strains supporting livestock mastitis. Fitoterapia 2014, 96, 1-7. [CrossRef] [PubMed]

126. Vratnica, B.D.; Đakov, T.; Šuković, D.; Damjanović, J. Antimicrobial effect of essential oil isolated from Eucalyptus globulus Labill. from Montenegro. Czech J. Food Sci. 2011, 29, 277-284.

127. Derwich, E.; Benziane, Z.; Boukir, A. GC/MS analysis of volatile constituents and antibacterial activity of the essential oil of the leaves of Eucalyptus globulus in Atlas Median from Morocco. Adv. Nat. Appl. Sci. 2009, 3, 305-313.

128. Luis, A.; Duarte, A.; Gominho, J.; Domingues, F.; Duarte, A.P. Chemical composition, antioxidant, antibacterial and anti-quorumsensing activities of Eucalyptus globulus and Eucalyptus radiata essential oils. Ind. Crops Prod. 2016, 79, 274-282. [CrossRef]

129. Alzogaray, R.A.; Lucia, A.; Zerba, E.N.; Masuh, H.M. Insecticidal activity of EOs from eleven Eucalyptus spp. and two hybrids: Lethal and sublethal effects of their major components on Blattella germânica. J. Econ. Entomol. 2011, 104, 595-600. [CrossRef] [PubMed]

130. Lucia, A.; Gonzalez, A.P.; Seccacini, E.; Licastro, S.; Zerba, E.; Masuh, H.M. Larvicidal effect of Eucalyptus grandis essential oil and turpentine and their major components on Aedes aegypti larvae. J. Am. Mosq. Control Assoc. 2007, 23, 299-303. [CrossRef]

131. Gillij, Y.G.; Gleiser, R.M.; Zygadlo, J.A. Mosquito repellent activity of EOs of aromatic plants growing in Argentina. Bioresour. Technol. 2008, 99, 2507-2515. [CrossRef] [PubMed]

132. Sartorelli, P.; Marquioreto, A.D.; Amaral-Baroli, A.; Lima, M.E.L.; Moreno, P.R.H. Chemical composition and antimicrobial activity of the EOs from two species of Eucalyptus. Phytotherapy 2007, 21, 231-233. [CrossRef] [PubMed] 
133. Bett, P.K.; Deng, A.L.; Ogendob, J.O.; Kariuki, S.T.; Kamatenesi-Mugisha, M.; Mihale, J.M.; Torto, B. Chemical composition of Cupressus lusitanica and Eucalyptus saligna leaf essential oils and bioactivity against major insect pests of stored food grains. Ind. Crops Prod. 2016, 82, 51-62. [CrossRef]

134. Alitonou, G.; Avlessi, F.; Wotto, V.D.; Ahoussi, E.; Dangou, J.; Sohounhloué, D.C.K. Composition chimique, propriétés antimicrobiennes et activités sur les tiques de l'huile essentielle d'Eucalyptus tereticornis Sm. C. R. Chim. 2004, 7, 1051-1055. [CrossRef]

135. Silva, S.M.; Abe, S.Y.; Bueno, F.G.; Lopes, N.P.; Mello, J.C.P.; Nakashima, T. Direct proof by ${ }^{13}$ C-nuclear magnetic resonance of semi-purified extract and isolation of ent-Catechin from leaves of Eucalyptus cinerea. Pharmacogn. Mag. 2014, 10, 191-194. [PubMed]

136. Batish, D.R.; Singh, H.P.; Kohli, R.K.; Kaur, S. Eucalyptus essential oil as a natural pesticide. For. Ecol. Manag. 2008, 256, 2166-2174. [CrossRef]

137. Castro, N.E.A.; Carvalho, G.J.; Cardoso, M.G.; Pimentel, F.A.; Correa, R.M.; Guimarães, L.G.L. Avaliação de rendimento e dos constituintes químicos do óleo essencial de folhas de Eucalyptus citriodora Hook. colhidas em diferentes épocas do ano em municípios de Minas Gerais. Rev. Bras. Med. 2008, 10, 70-75.

138. Martins, F.T.; Santos, M.H.; Polo, M.; Barbosa, L.C.A. Chemical variation in the essential oil of Hyptis suaveolens (L.) Poit., under cultivation condition. Quím. Nova 2006, 29, 1203-1209. [CrossRef]

139. Martins, F.T.; Santos, M.H.; Polo, M.; Barbosa, L.C.A. Effects of the interactions among macronutrients, plant age and photoperiod in the composition of Hyptis suaveolens (L.) Poit essential oil from Alfenas (MG), Brazil. Flavour Fragr. J. 2007, 22, 123-129. [CrossRef]

140. Castro, H.G.; Oliveira, L.O.; Barbosa, L.C.A.; Ferreira, F.A.; Silva, D.J.H.; Mosquim, P.R.; Nascimento, E.A. Teor e composição do óleo essencial de cinco acessos de mentrasto. Quím. Nova 2004, 27, 55-57. [CrossRef]

141. Silva, C.J.; Barbosa, L.C.A.; Maltha, C.R.A.; Pinheiro, A.L.; Ismail, F.M.D. Comparative study of the essential oils of seven Melaleuca (Myrtaceae) species grown in Brazil. Flavour Fragr. J. 2007, 22, 474-478. [CrossRef]

142. Bayala, B.; Bassole, I.H.N.; Gnoula, C.; Nebie, R.; Yonli, A.; Morel, L.; Figueredo, G.; Nikiema, J.; Lobaccaro, J.A.; Simpore, J. Chemical composition, antioxidant, anti-inflammatory and anti-proliferative activities of EOs of plants from Burkina Faso. PLoS ONE 2014, 9, e92122. [CrossRef] [PubMed]

143. Deba, F.; Xuan, T.D.; Yasuda, M.; Tawata, S. Chemical composition and antioxidant, antibacterial and antifungal activities of the EOs from Bidens pilosa Linn. var. Radiata. Food Control 2008, 19, 346-352. [CrossRef]

144. Pauli, A. Anticandidal low molecular compounds from higher plants with special reference to compounds from EOs. Med. Res. Rev. 2006, 26, 223-268. [CrossRef] [PubMed]

145. Sacchetti, G.; Maietti, S.; Muzzoli, M.; Scaglianti, M.; Manfredini, S.; Radice, M.; Bruni, R. Comparative evaluation of 11 EOs of different origin as functional antioxidants, antiradicals and antimicrobials in foods. Food Chem. 2005, 91, 621-632. [CrossRef]

146. Thuille, N.; Fille, M.; Nagl, M. Bactericidal activity of herbal extracts. Int. J. Hyg. Envir. Health 2003, 206, 217-221. [CrossRef] [PubMed]

147. Valero, M.; Salmeron, M.C. Antibacterial activity of 11 EOs against Bacillus cereus in tyndallized carrot broth. Int. J. Food Microbiol. 2003, 85, 73-81. [CrossRef]

148. Bugarin, D.; Grbovic, S.; Orcic, D.; Mitic-Culafic, D.; Knezevic-Vukcevic, J.; Mimica-Dukic, N. Essential oil of Eucalyptus gunnii Hook. as a novel source of antioxidant, antimutagenic and antibacterial agents. Molecules 2014, 19, 19007-19020. [CrossRef] [PubMed]

149. Rosato, A.; Vitali, C.; Laurentis, N.; Armenise, D.; Milillo, M.A. Antibacterial effect of some EOs administered alone or in combination with Norfloxacin. Phytomedicine 2007, 14, 727-732. [CrossRef] [PubMed]

150. Sonboli, A.; Babakhani, B.; Mehrabian, A.R. Antimicrobial activity of six constituents of essential oil from Salvia. Z. Naturforsch. C 2006, 61, 160-164. [CrossRef] [PubMed]

151. Ghalem, B.R.; Mohamed, B. Antibacterial activity of leaf EOs of Eucalyptus globulus and Eucalyptus camaldulensis. Afr. J. Pharm. Pharmacol. 2008, 2, 211-215.

152. Elaissi, A.; Rouis, Z.; Salem, N.A.B.; Mabrouk, S.; Salem, Y.B.; Salah, K.B.H.; Aouni, M.; Farhat, F.; Chemli, R.; Harzallah-Skhiri, F.; et al. Chemical composition of 8 Eucalyptus species' EOs and the evaluation of their antibacterial, antifungal and antiviral activities. Complement. Altern. Med. 2012, 12, 81. [CrossRef] [PubMed] 
153. Elaissi, A.; Rouis, Z.; Mabrouk, S.; Salah, K.B.H.; Aouni, M.; Khouja, M.L.; Farhat, F.; Chemli, R.; Harzallah-Skhiri, F. Correlation between chemical composition and antibacterial activity of EOs from fifteen Eucalyptus species. Growing in the Korbous and Jbel Abderrahman Arboreta (North East Tunisia). Molecules 2012, 17, 3044-3057. [CrossRef] [PubMed]

154. Delaquis, P.J.; Stanich, K.; Girard, B.; Mazza, G. Antimicrobial activity of individual and mixed fractions of dill, cilantro, coriander and Eucalyptus EOs. Int. J. Food Microbiol. 2002, 74, 101-109. [CrossRef]

155. Marzoug, H.N.B.; Bouajila, J.; Ennajar, M.; Lebrihi, A.; Mathieu, F.; Couderc, F.; Abderraba, M.; Romdhane, M. Eucalyptus (gracilis, oleosa, salubris, and salmonophloia) EOs: Their chemical composition and antioxidant and antimicrobial activities. J. Med. Food 2010, 13, 1005-1012. [CrossRef] [PubMed]

156. Proenza, Y.G.; Álvarez, R.Q.; Tamayo, Y.V.; Saavedra, M.A.; García, Y.S.; Espinosa, R.H. Chemical composition and antibacterial activity of the essential oil from Eucalyptus pellita F. Muell. J. Med. Plants Res. 2013, 7, 1979-1983.

157. Safaei-Ghomi, J.; Batooli, H. Chemical composition and antimicrobial activity of the volatile oil of Eucalyptus sargentii Maiden cultivated in central Iran. Int. J. Green Pharm. 2010, 4, 174-177. [CrossRef]

158. Ghnaya, A.B.; Hanana, M.; Amri, I.; Balti, H.; Gargouri, S.; Jamoussi, B.; Hamrouni, L. Chemical composition of Eucalyptus erythrocorys EOs and evaluation of their herbicidal and antifungal activities. J. Pest Sci. 2013, 86, 571-577. [CrossRef]

159. Camara, B.; Dick, E.; Sako, A.; Kone, D.; Kanko, C.; Boye, M.A.D.; Ake, S.; Anno, A. Lutte biologique contre Deightoniella torulosa (Syd.) Ellis, par l'application des huiles essentielles d'Eucalyptus platyphylla F. Muell. et de Melaleuca quinquenervia L. Phytothérapie 2010, 8, 240-244. [CrossRef]

160. Baptista, E.B.; Zimmermann-Franco, D.C.; Lataliza, A.A.B.; Raposo, N.R.B. Chemical composition and antifungal activity of essential oil from Eucalyptus smithii against dermatophytes. Rev. Soc. Bras. Med. Trop. 2015, 48, 746-752.

161. Ye, C.L.; Dai, D.H.; Hu, W.L. Antimicrobial and antioxidant activities of the essential oil from onion (Allium cepa L.). Food Control 2013, 30, 48-53. [CrossRef]

162. Singh, N.; Rajini, P.S. Free radical scavenging activity of an aqueous extract of potato peel. Food Chem. 2004, 85, 611-616. [CrossRef]

163. Puupponen-Pimiä, R.; Nohynek, L.; Meier, C.; Kähkönen, M.; Heinonen, M.; Hopia, A. Antimicrobial properties of phenolic compounds from berries. J. Appl. Microbiol. 2001, 90, 494-507. [CrossRef] [PubMed]

164. Cermelli, C.; Fabio, A.; Fabio, G.; Quaglio, P. Effect of Eucalyptus essential oil on respiratory bacteria and viruses. Curr. Microbiol. 2008, 56, 89-92. [CrossRef] [PubMed]

165. Srivastava, B.; Singh, P.; Shukla, R.; Dubey, N.K. A novel combination of the EOs of Cinnamomum camphora and Alpinia galanga in checking aflatoxin B1 production by a toxigenic strain of Aspergillus flavus. World J. Microbiol. Biotechnol. 2008, 24, 693-697. [CrossRef]

166. Roh, H.S.; Lee, B.H.; Park, C.G. Acaricidal and repellent effects of myrtacean EOs and their major constituents against Tetranychus urticae (Tetranychidae). J. Asia-Pac. Entomol. 2013, 16, 245-249. [CrossRef]

167. Clemente, M.A.; Monteiro, C.M.O.; Scoralik, M.G.; Gomes, F.T.; Prata, M.C.A.; Daemon, E. Acaricidal activity of the EOs from Eucalyptus citriodora and Cymbopogon nardus on larvae of Amblyomma cajennense (Acari: Ixodidae) and Anocentor nitens (Acari: Ixodidae). Parasitol. Res. 2010, 107, 987-992. [CrossRef] [PubMed]

168. Ware, G.W. The Pesticide Book, 5th ed.; Thomson Publicaions: Fresno, CA, USA, 1999.

169. Moreira, M.D.; Picanço, M.C.; Barbosa, L.C.A.; Guedes, R.N.C.; Silva, E.M. Toxicity of leaf extracts of Ageratum conyzoides to lepidoptera pests of horticultural crops. Biol. Agric. Hortic. 2004, 22, 251-260. [CrossRef]

170. Moreira, M.D.; Picanço, M.C.; Barbosa, L.C.A.; Guedes, R.N.C.; Barros, E.C.; Campos, M.R. Compounds from Ageratum conyzoides: Isolation, structural elucidation and insectide activity. Pest Manag. Sci. 2007, 63, 615-621. [CrossRef] [PubMed]

171. Moreira, M.D.; Picanço, M.C.; Barbosa, L.C.A.; Guedes, R.N.C.; Campos, M.R.; Silva, G.A.; Martins, J.C. Plant Compounds insecticide activity against Coleoptera pests of stored products. Pesq. Agropec. Bras. 2007, 42, 909-915. [CrossRef]

172. Tjahjani, S. Efficacy of several EOs as Culex and Aedes repellents. Proc. ASEAN Congress Trop. Med. Parasitol. 2008, 3, 33-37.

173. Sophia, N.; Pandian, R.S. Screening of the efficacy of phytochemical repellents against the filarial vector mosquito, Culex quinquefasciatus Say. Curr. Biot. 2009, 3, 14-31. 
174. Govindarajan, M. Larvicidal and repellent properties of some EOs against Culex tritaeniorhynchus Giles and Anopheles subpictus Grassi (Diptera: Culicidae). Asian Pac. J. Trop. Med. 2011, 4, 106-111. [CrossRef]

175. Mandal, S. Repellent activity of Eucalyptus and Azadirachta indica seed oil against the filarial mosquito Culex quinquefasciatus Say. (Diptera: Culicidae) in India. Asian Pac. J. Trop. Biomed. 2011, 1, S109-S112. [CrossRef]

176. Tennyson, S.; Ravindran, J.; Eapen, A.; Willian, J. Repellent activity of Ageratum houstonianum Mill. (Asteraceae) leaf extracts against Anopheles stephensi, Aedes aegypti and Culex quinquefasciatus (Diptera: Culicidae). Asian Pac. J. Trop. Dis. 2012, 6, 478-480. [CrossRef]

177. Gokulakrishnan, J.; Kuppusamy, E.; Shanmugam, D.; Appavu, A.; Kaliyamoorthi, K. Pupicidal and repellent activities of Pogostemon cablin essential oil chemical compounds against medically important human vector mosquitoes. Asian Pac. J. Trop. Dis. 2013, 3, 26-31. [CrossRef]

178. Nerio, L.S.; Olivero-Verbel, J.; Stashenko, E. Repellent activity of EOs: A review. Bioresour. Technol. 2010, 101, 372-378. [CrossRef] [PubMed]

179. Murugan, K.; Murugan, P.; Noortheen, A. Larvicidal and repellent potential of Albizzia amara Boivin and Ocimum basilicum Linn against dengue vector, Aedes aegypti (Insecta: Diptera: Culicidae). Bioresour. Technol. 2007, 98, 198-201. [CrossRef] [PubMed]

180. Choochote, W.; Chaithong, U.; Kamsuk, K.; Jitpakdi, A.; Tippawangkosol, P.; Tueton, B.; Champakaew, D.; Pitasawat, B. Repellent activity of selected EOs against Aedes aegypti. Fitoterapia 2007, 78, 359-364. [CrossRef] [PubMed]

181. Phasomkusolsil, S.; Soonwera, M. Efficacy of herbal EOs as insecticide against Aedes aegypti (Linn.), Culex quinquefasciatus (Say.) and Anopheles dirus (Peyton and Harrison). Southeast Asian J. Trop. Med. Public Health 2011, 42, 1083-1092. [PubMed]

182. Krishnappa, K.; Elumalai, K. Toxicity of Aristolochia bracteata methanol leaf extract against selected medically important vector mosquitoes (Diptera: Culicidae). Asian Pac. J. Trop. Dis. 2012, 2, S553-S557. [CrossRef]

183. Govindarajan, M. Chemical composition and larvicidal activity of leaf essential oil from Clausena anisata (Willd.) Hook. f. ex Benth (Rutaceae) against three mosquito species. Asian Pac. J. Trop. Med. 2010, 3, 874-877. [CrossRef]

184. Govindarajan, M.; Sivakumar, R. Repellent properties of Cardiospermum halicacabum Linn. (Family: Sapindaceae) plant leaf extracts against three important vector mosquitoes. Asian Pac. J. Trop. Biomed. 2012, 8, 602-607. [CrossRef]

185. Aarthi, N.; Murugan, K. Larvicidal and repellent activity of Vetiveria zizanioides L, Ocimum basilicum Linn and the microbial pesticide spinosad against malarial vector, Anopheles stephensi Liston (Insecta: Diptera: Culicidae). J. Biopestic. 2010, 3, 199-204.

186. Ali, A.; Murphy, C.C.; Demirci, B.; Wedge, D.W.; Sampson, B.J.; Khan, I.A.; Baser, K.H.C.; Tabanca, N. Insecticidal and biting deterrent activity of rose-scented geranium (Pelargonium spp.) EOs and individual compounds against Stephanitis pyrioides and Aedes aegypti. Pest Manag. Sci. 2013, 69, 1385-1392. [CrossRef] [PubMed]

187. Ali, A.; Tabanca, N.; Demirci, B.; Baser, K.H.C.; Ellis, J.; Gray, S.; Lackey, B.R.; Murphy, C.; Khan, I.A.; Wedge, D.E. Composition, mosquito larvicidal, biting deterrent and antifungal activity of EOs of different plant parts of Cupressus arizonica var. glabra ('Carolina Sapphire'). Nat. Prod. Commun. 2013, 8, 257-260. [PubMed]

188. Hoel, D.; Pridgeon, J.W.; Bernier, U.R.; Chauhan, K.; Meepagala, K.; Cantrell, C. Departments of Defense and Agriculture team up to develop new insecticides for mosquito control. Wing Beats 2010, 21, 19-34.

189. Nascimento, J.C.; David, J.M.; Barbosa, L.C.A.; Paula, V.F.; Demuner, A.J.; David, J.P.; Conserva, L.M.; Ferreira, J.C.; Guimarães, E.F. Larvicidal activities and chemical composition of essential oils from Piper klotzschianum (Kunth) C. DC. (Piperaceae). Pest Manag. Sci. 2013, 69, 1267-1271. [PubMed]

190. Pavela, R. Larvicidal property of EOs against Culex quinquefasciatus Say. (Diptera: Culicidae). Ind. Crops Prod. 2009, 30, 311-315. [CrossRef]

191. Pavela, R. Larvicidal effects of some Euro-Asiatic plants against Culex quinquefasciatus Say larvae (Diptera: Culicidae). Parasitol. Res. 2009, 105, 887-892. [CrossRef] [PubMed]

192. Tabanca, N.; Bernier, U.R.; Ali, A.; Wang, M.; Demirci, B.; Blythe, E.K.; Khan, S.I.; Baser, K.H.C.; Khan, I.A. Bioassay-guided investigation of two Monarda EOs as repellents of yellow fever mosquito Aedes aegypti. J. Agric. Food Chem. 2013, 61, 8573-8580. [CrossRef] [PubMed] 
193. Wedge, D.E.; Klun, J.A.; Tabanca, N.; Demirci, B.; Ozek, T.; Baser, K.H.C.; Liu, Z.; Zhang, S.; Cantrell, C.L.; Zhan, J. Bioactivity-guided fractionation and GC/MS fingerprinting of Angelica sinensis and Angelica archangelica root components for antifungal and mosquito deterrent activity. J. Agric. Food Chem. 2009, 57, 464-470. [CrossRef] [PubMed]

194. Hamdi, S.H.; Hedjal-Chebheb, M.; Kellouche, A.; Khouja, M.L.; Boudabous, A.; Jemaa, J.M.B. Management of three pests' population strains from Tunisia and Algeria using Eucalyptus essential oils. Ind. Crops Prod. 2015, 74, 551-556. [CrossRef]

195. Juan, L.; Lucia, A.; Zerba, E.; Harrand, L.; Marco, M.; Masuh, H. Chemical composition and fumigant toxicity of the EOs from 16 species of Eucalyptus against Haematobia irritans (L.) (Diptera: Muscidae) adults. J. Econ. Entomol. 2011, 104, 1087-1092. [CrossRef] [PubMed]

196. Lucia, A.; Juan, L.W.; Zerba, E.N.; Harrand, L.; Marcó, M.; Masuh, H.M. Validation of models to estimate the fumigant and larvicidal activity of Eucalyptus EOs against Aedes aegypti (Diptera: Culicidae). Parasitol. Res. 2012, 110, 1675-1686. [CrossRef] [PubMed]

197. Aref, S.P.; Valizadegan, O.; Farashiani, M.E. Eucalyptus dundasii Maiden essential oil, chemical composition and insecticidal values against Rhyzopertha dominica (F.) and Oryzaephilus surinamensis (L.). J. Plant Prot. Res. 2015, 55, 35-41. [CrossRef]

198. Aref, S.P.; Valizadegan, O.; Farashiani, M.E. The insecticidal effect of essential oil of Eucalyptus floribundi against two major stored product insect pests; Rhyzoperth dominica (F.) and Oryzaephilus surinamensis (L.). J. Essent. Oil Bear. Plants 2016, 19, 820-831. [CrossRef]

199. Rajendran, S.; Sriranjini, V. Plant products as fumigants for stored-product insect control. J. Stored Prod. Res. 2008, 44, 126-135. [CrossRef]

200. Houghton, P.J.; Ren, Y.; Howes, M.J. Acetylcholinesterase inhibitors from plants and fungi. Nat. Prod. Rep. 2006, 23, 181-199. [CrossRef] [PubMed]

201. Seyoum, A.; Killeen, G.F.; Kabiru, E.W.; Knols, B.G.J.; Hassanali, A. Field efficacy of thermally expelled or live potted repellent plants against African malaria vectors in western Kenya. Trop. Med. Int. Health 2003, 8 , 1005-1011. [CrossRef] [PubMed]

202. Nathan, S.S. The use of Eucalyptus tereticornis Sm: (Myrtaceae) oil (leaf extract) as a natural larvicidal agent against the malaria vector Anopheles stephensi Liston (Diptera: Culicidae). Bioresour. Technol. 2007, 98, 1856-1860.

203. Coob, A.H.; Reade, J.P.H. Herbicides and Plant Physiology, 2nd ed.; Wiley-Blackwell: Chichester, UK, 2010; p. 286.

204. Dayan, F.E.; Cantrell, C.L.; Duke, S.O. Natural products in crop protection. Bioorg. Med. Chem. 2009, 17, 4022-4034. [CrossRef] [PubMed]

205. Zanic, K.; Goreta, S.; Perica, S.; Sutik, J. Effects of alternative pesticides on greenhouse whitefly in protected cultivation. J. Pest Sci. 2008, 81, 161-166. [CrossRef]

206. Seyran, M.; Brenneman, T.B.; Stevenson, K.L. In vitro toxicity of alternative oxidase inhibitors salicylhydroxamic acid and propyl gallate on Fusicladium effusum. J. Pest Sci. 2010, 83, 421-427. [CrossRef]

207. Yangui, T.; Sayadi, S.; Rhouma, A.; Dhouib, A. Potential use of hydroxytyrosol-rich extract from olive mill wastewater as a biological fungicide against Botrytis cinerea in tomato. J. Pest Sci. 2010, 83, 437-445. [CrossRef]

208. Varejao, E.V.V.; Demuner, A.J.; Barbosa, L.C.A.; Barreto, R.W. The search for new natural herbicides-Strategic approaches for discovering fungal phytotoxins. Crop Prot. 2013, 48, 41-50. [CrossRef]

209. Douda, O.; Zouhar, M.; Mazáková, J.; Novácová, E.; Pavela, R. Using plant essence as alternatives mean for northern root-knot nematode (Meloidogyne hapla) management. J. Pest Sci. 2010, 83, 217-221. [CrossRef]

210. Batish, D.R.; Setia, N.; Singh, H.P.; Kohli, R.K. Phytotoxicity of lemon-scented eucalypt oil and its potential use as a bioherbicide. Crop Prot. 2004, 23, 1209-1214. [CrossRef]

211. Setia, N.; Batish, D.R.; Singh, H.P.; Kohli, R.K. Phytotoxicity of volatile oil from Eucalyptus citriodora against some weedy species. J. Environ. Biol. 2007, 28, 63-66. [PubMed]

212. Zhang, J.; An, M.; Wu, H. Chemical composition of EOs of four Eucalyptus species and their phytotoxicity on silver leaf nightshade (Solanum elaeagnifolium Cav.) in Australia. Plant Growth Regul. 2012, 68, 231-237. [CrossRef]

213. Zhang, J.; An, M.; Wu, H.; Liu, D.L.; Stanton, R. Phytotoxic activity and chemical composition of aqueous volatile fractions from Eucalyptus species. PLoS ONE 2014, 9, e93189. [CrossRef] [PubMed] 
214. Qiu, X.; Yu, S.; Wang, Y.; Fang, B.; Cai, C.; Liu, S. Identification and allelopathic effects of 1,8-cineole from Eucalyptus urophylla on lettuce. Allelopathy J. 2010, 26, 255-264.

215. Vivan, G.A.; Barboza, F.S.; Luz, M.L.G.S.; Luz, C.A.S.; Pereira-Ramirez, O.; Gomes, M.C.; Soares, F.C. Estudo técnico e econômico de um sistema móvel de extração de óleo essencial de eucalipto. Cerne 2011, 17, $23-31$. [CrossRef]

216. Coppen, J.J.W.; Hone, G.A. Eucalyptus Oils-A Review of Production and Markts—Bulletin 56; Natural Resources Institute, University of Greenwich: London, England, 1992.

217. Lassak, E.V. The Australian Eucalyptus oil industry, past and present. Chem. Aust. 1998, 55, 396-398.

218. Doran, J.C. Commercial sources, uses, formation, and biologyc. In Eucalyptus Leaf Oils: Use, Chemistry, Distillation and Marketing; Boland, D., Brophy, J., House, J.J., Eds.; Inkata: Melbourne, Australia, 1991; pp. 11-28.

219. Silva, J.C. Eucalipto: Pesquisa amplia usos: Perspectivas do setor florestal Brazileiro. Rev. Madeira 2003, 13, 4-6.

220. Coppen, J.J.W. Productions, trade and markets for Eucalyptus oil. In Eucalyptus-The Genus Eucalyptus; Coppen, J.J.W., Ed.; Taylor and Francis: London, UK, 2005; Chapter 17; pp. 365-383.

(C) 2016 by the authors; licensee MDPI, Basel, Switzerland. This article is an open access article distributed under the terms and conditions of the Creative Commons Attribution (CC-BY) license (http://creativecommons.org/licenses/by/4.0/). 